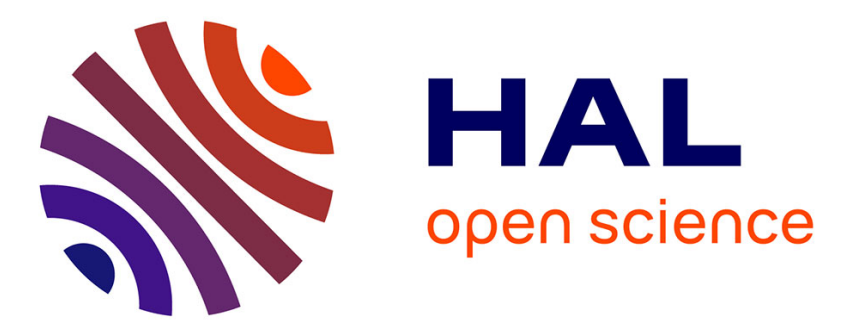

\title{
Strengthening Peptoid Helicity through Sequence Site-Specific Positioning of Amide Cis-Inducing Nt Bu monomers
}

\author{
Maha Rzeigui, Mounir Traikia, Laurent Jouffret, Alexandre Kriznik, \\ Jameleddine Khiari, Olivier Roy, Claude Taillefumier
}

\section{To cite this version:}

Maha Rzeigui, Mounir Traïkia, Laurent Jouffret, Alexandre Kriznik, Jameleddine Khiari, et al.. Strengthening Peptoid Helicity through Sequence Site-Specific Positioning of Amide Cis-Inducing Nt Bu monomers. Journal of Organic Chemistry, 2020, 85 (4), pp.2190-2201. 10.1021/acs.joc.9b02916 . hal-02430577

\section{HAL Id: hal-02430577 \\ https://hal.univ-lorraine.fr/hal-02430577}

Submitted on 3 Feb 2022

HAL is a multi-disciplinary open access archive for the deposit and dissemination of scientific research documents, whether they are published or not. The documents may come from teaching and research institutions in France or abroad, or from public or private research centers.
L'archive ouverte pluridisciplinaire HAL, est destinée au dépôt et à la diffusion de documents scientifiques de niveau recherche, publiés ou non, émanant des établissements d'enseignement et de recherche français ou étrangers, des laboratoires publics ou privés. 


\title{
"Strengthening Peptoid Helicity through Sequence Site-Specific Positioning of Amide Cis-Inducing NtBu monomers"
}

\author{
Maha Rzeigui, a,d Mounir Traikia, ${ }^{\mathrm{a}}$ Laurent Jouffret, ${ }^{\mathrm{a}}$ Alexandre Kriznik, ${ }^{\mathrm{b}, \mathrm{c}}$ \\ Jameleddine Khiari, ${ }^{d}$ Olivier Roy, a and Claude Taillefumier*,a
}

aUniversité Clermont Auvergne, CNRS, SIGMA Clermont, ICCF, F-63000 Clermont-Ferrand, France

bUniversité de Lorraine, CNRS, IMoPA, F-54000 Nancy, France

cUniversité de Lorraine, CNRS, Inserm, UMS2008 IBSLor, Biophysics and Structural Biology core facility, F-54000 Nancy, France

dUniversité de Carthage, Faculté Des Sciences de Bizerte, Laboratoire de Chimie Organique et Analytique, ISEFC, 2000, Bardo, Tunisie

corresponding author : claude.taillefumier@uca.fr

Keywords: Peptoids; Polyproline type I helix, Cis-trans isomerization; Peptidomimetics

\begin{abstract}
The synthesis of biomimetic helical secondary structures is sought after for the construction of innovative nanomaterials and applications in medicinal chemistry such as the development of protein-protein interactions modulators. Peptoids, a sequence-defined family of oligomers, enable a peptidomimetic strategy, especially considering the easily accessible monomer diversity and peptoid helical folding propensity. However, cis-trans isomerization of the backbone tertiary amides may impair the peptoid's adoption of stable secondary structures, notably the all-cis polyproline I-like helical conformation. Here we show that cis-inducing $N t \mathrm{Bu}$ achiral monomers strategically positioned within chiral sequences may reinforce the degree of peptoid helicity, although a reduced content of chiral side chains. The design principles presented here will undoubtedly help to achieve more conformationally stable helical peptoids with desired functions.
\end{abstract}




\section{INTRODUCTION}

$N$-substituted glycine oligomers, also called "peptoids" have emerged as a very attractive class of synthetic amide-based oligomers. There are many reasons for this, ranging from their ease of synthesis with unique side chain diversity ${ }^{1}$ to their conformational versatility which opens up a wide range of potential applications relevant to biomaterial science ${ }^{2,3}$, therapeutics development, 4,5,6 and catalysis. ${ }^{7,8,9}$

Peptoids should be regarded as biotic foldamers since their backbone closely resembles that of peptides with the side chains attached to the amide nitrogen atoms rather than the C $\alpha$ carbons, and also because single-chain peptoids may exhibit biopolymer-like conformational behaviours. The iterative "submonomer" method ${ }^{10}$ used to synthesise peptoids generates sequence-defined oligomers with protease-resistant tertiary amide bonds, ${ }^{11,12}$ a desirable property for developing peptidomimetic ligands and biomimetic discrete secondary structures. Peptoids have been shown to fold in a variety of secondary structures, some of which are reminiscent those of peptides, like helices, sheets and turns, ${ }^{13,14,15,16,17,18,19}$ and others are singular like square helices and ribbons. $^{20,21,22}$ However, cis-trans isomerisation of the peptoid tertiary amide bonds ( $N, N$ disubstituted amides) is a source of conformational heterogeneity ${ }^{23,24}$ which may impair the formation of well-defined secondary structures. A number of research groups have engineered peptoid side chains that allow a local control of the dihedral angles through a set of backbone to side chain and side chain to side chain weak non-covalent interactions. ${ }^{25,26,27,28,29,30,31}$ Two peptoid helical conformations have been characterized; one of them has an overall shape resembling the naturally-occurring polyproline II, an extended all-trans helix most frequently occurring in proline-rich sequences. The other one resembles the all-cis polyproline I helix (PPI) which is characterised by a three-fold periodicity and a helical pitch of approximate to 6 Angstrom. The latter has been observed for proline-rich sequences in hydrophobic solvents, like $n$-PrOH. ${ }^{32}$ Zuckermann was the first to uncover the role of $N \alpha$ chiral aromatic peptoid side chains, typically $(S)$ - or $(R)$-1-phenylethyl (spe/rpe) side chain, on the folding into the PPI-like conformation. $^{33}(S)-N$-(1-phenylethyl)glycine monomers are, for example, commonly used to induce right-handed helices. ${ }^{9,34,35}$ Sequence requirements and chain length effects were carefully studied which established the rules for the formation and stabilisation of chiral PPI-type helical secondary structures from aromatic-containing monomers. ${ }^{36,37,38}$ In contrast, the control of peptoid helicity from non-aromatic monomers has been much less investigated. ${ }^{14,30}$ Recently we started to explore new avenues for stabilizing PPI-like peptoid helices avoiding aromatic side chains. Two novel aliphatic side chains were added to the peptoid "toolbox", the bulky tert-butyl 
and tert-butylethyl side chains, the monomers of which have been termed $N t \mathrm{Bu}$ and $N$ s1tbe $(S$ configuration) (Figure 1). The very bulky tert-butyl group is the only one known to lock peptoid amide bonds in the cis conformation. ${ }^{29} \mathrm{X}$-ray crystal structures of $\mathrm{Nt} \mathrm{Bu}$ oligomers showed their PPI-like helix folding and calculations revealed that this conformation is stabilized through weak non-covalent interactions, notably London interactions between $t \mathrm{Bu}$ side chains located on the same face of the helix. ${ }^{30}$ Nonetheless, the lack of $N C \alpha$ stereogenic center means that the $\varphi$ dihedral angles may adopt + and - values (around $85^{\circ}$, Figure 1a) which results in conformational heterogeneity in solution. On the other hand, the chiral aliphatic tert-butylethyl side chain is one of the best cis-peptoid amide inducer allowing the formation of discrete PPI helices of defined handedness. ${ }^{16}$

Interestingly, an increase of helicity was observed by $\mathrm{CD}$ spectroscopy for the mixed Ac-NtBu$(N \mathrm{~s} 1 \text { tbe })_{4}-N t \mathrm{Bu}-\mathrm{O} t \mathrm{Bu}$ and $\mathrm{Ac}-(N t \mathrm{Bu})_{2}-(N \mathrm{~s} 1 \text { tbe })_{4}-(N t \mathrm{Bu})_{2}-\mathrm{O} t \mathrm{Bu}$ oligomers, compared to their parent homo-oligomers composed solely of $N$ s 1 tbe residues. This observation was correlated to an increase of cis-amide bonds population for the Ns1tbe monomers, suggesting that the two types of monomers can act synergistically to achieve extremely robust helices of defined handedness. Proof of this is the solid state structure of the octamer Ac- $(N t \mathrm{Bu})_{2}-(N \mathrm{~s} 1 \mathrm{tbe})_{4-}$ $(N t \mathrm{Bu})_{2}-\mathrm{O} t \mathrm{Bu}$, the longest linear peptoid ever solved which revealed a right-handed helix of great regularity despite only a 50\% content of chiral monomers. These fascinating results evoking a Sergeant-and-Soldiers behaviour ${ }^{39}$ encouraged us to pursue our investigations. Here we address the questions of the amount and site-specific placement of achiral $\mathrm{N} t \mathrm{Bu}$ glycine monomers within $N$ s1tbe sequences with respect to peptoid helicity. 2D NMR HSQCAD experiments were used to determine the overall backbone amide $K_{\text {cistrans }}$ in deuterated chloroform and acetonitrile and, CD spectroscopy to evaluate variation of peptoid helicity. Two crystal structures are also reported with backbone dihedral angles corresponding to the PPI helix. 
a) Achiral NtBu monomer

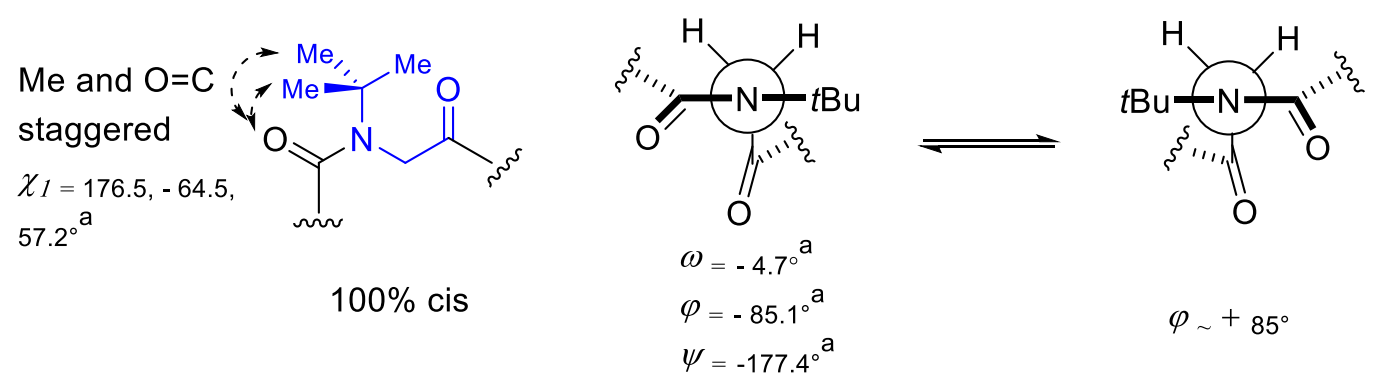

b) Chiral Ns1tbe monomer
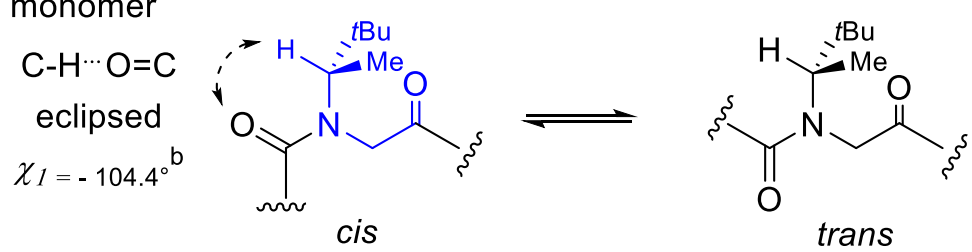

$$
\begin{aligned}
& \omega=-14.3^{\circ \mathrm{b}} \\
& \varphi=-68.2^{\circ}{ }^{\circ} \\
& \psi=-178.8^{\circ}
\end{aligned}
$$

Figure 1.Structure and conformational characteristics of the $N t \mathrm{Bu}$ and $N$ s1tbe peptoid residues used in this study (drawn in blue), see table 2 for the dihedral angles definition. ${ }^{\text {a }}$ Measured for the central residue of the crystal structure of $\mathrm{H}-(\mathrm{Nt} \mathrm{Bu})_{5}-\mathrm{OBn} .{ }^{30}{ }^{\mathrm{b}}$ Measured for the central residue of the crystal structure of $\mathrm{Ac}-(N \mathrm{~s} 1 \text { tbe })_{5}-\mathrm{O} t \mathrm{Bu}^{16}$. The $\chi_{1}$ angles have been measured for each $t \mathrm{Bu}$ $\mathrm{NC}_{\beta}$ methyl carbon in case of the representative $N t \mathrm{Bu}$ monomer; the $t \mathrm{Bu} \mathrm{NC} /$ has been used for measuring the $\chi_{1}$ angle (-104.4) in case of the representative $N$ s1 tbe monomer. 


\section{RESULTS AND DISCUSSION}

Design and synthesis of peptoid oligomers 1-16. Recently, we have proposed two efficient structure-inducing peptoid side chains avoiding aromatic groups: the tert-butyl $(t \mathrm{Bu})$ and $(S)-1$ tert-butylethyl (s1tbe) side chains. The following two mixed peptoids Ac-NtBu-(Ns1tbe)4-NtBu$\mathrm{O} t \mathrm{Bu}(\mathrm{A})$ and $\mathrm{Ac}-(N t \mathrm{Bu})_{2}-(N \mathrm{~s} 1 \text { tbe })_{4}-(N t \mathrm{Bu})_{2}-\mathrm{O} t \mathrm{Bu}(\mathbf{B})$ of 6 and 8 residues in length have revealed a remarkable level of helicity. ${ }^{16}$ In the initial design, the $N \mathrm{tBu}$ monomers were positioned at the $N$ - and $C$-termini of the peptoid chains, and the amount of chiral side chain was $66 \%$ for the hexamer and 50\% for the octamer. The above results pose several questions: (1) Should the all-cis inducing $N t \mathrm{Bu}$ monomers be necessarily positioned at the extremities of the oligomers to enhance conformational homogeneity ? (2) Is a single $N t \mathrm{Bu}$ monomer capable of exerting such control over the conformation, and, if so, at which position should it be placed in the sequence? (3) Considering the initial design with the achiral monomers at the oligomer's end, to what extent the length of the chiral central Ns1tbe-based segment can be shortened? Conversely how many consecutive $N t \mathrm{Bu}$ residues can be placed at the extremities without affecting chiral induction from the center to both ends of the oligomers. Peptoid helix folding is a chain length-dependent process. ${ }^{37}$ For example, an increase of ellipticity was observed for $\mathrm{Nrpe}$ oligomers between 4 and 12 residues in length, suggesting that the helix with cis-amide bonds becomes the most favored conformation, only when the oligomer length of 11-13 residues is reached. Designing medium-size peptoids displaying a strong conformational stability is still challenging. For this reason and also because of the remarkable level of helicity of hexamer A, we chose to synthesize a first family of peptoid hexamers (1-6) enabling us to answer points (1) and (2) (Table 1). Peptoids 7-11 were designed to evaluate how the length of the chiral and achiral segments impact helicity (question 3 above) and peptoids 12-16 were prepared in order to evaluate oligomers composed of the same repeated ( $N t \mathrm{Bu}-N \mathrm{~s} 1$ tbe- $N \mathrm{~s} 1$ tbe) pattern, thus placing the $t \mathrm{Bu}$ side chains on the same face of the helical structure. This design is of particular importance since "functional versions" of the tert-butyl side chain of structure $\mathrm{NC}\left(\mathrm{CH}_{3}\right)_{2} \mathrm{CH}_{2} \mathrm{R}$ have been proposed. They allow mimicking amino acid side chains while retaining the conformational properties of the parent $t$ Bu group. ${ }^{40}$

In view of the difficulties experienced by our group for the solid-phase synthesis of $N t$ Bu-based oligomers, solution-phase synthesis was preferred in this study. ${ }^{41}$ Thus, peptoids 1-16 were synthesized via a solution-phase submonomer method (SI, Figure S1). All final compounds were isolated with purity greater than $95 \%$, as determined by integration of peaks with UV detection at $214 \mathrm{~nm}$, after purification by flash silica gel column chromatography or preparative RP-HPLC (see ESI for HPLC data). They were characterized by MS to confirm their identity (Table 1). 
Peptoids 1-16 were further analyzed by NMR experiments $\left({ }^{1} \mathrm{H},{ }^{13} \mathrm{C}\right.$, COSY, HSQC, HMBC and HSQCAD, see SI for NMR data) and two crystal structures were also obtained for peptoids 12 and 14.

Table 1. Sequence of the Peptoid Synthesized, Purity and Mass Spectra Data for Peptoids 1-16

\begin{tabular}{|c|c|c|c|c|c|}
\hline Peptoid & $l^{\mathrm{a}}$ & monomer sequence & $\begin{array}{c}\% \\
\text { purity }\end{array}$ & $\begin{array}{l}\text { expected } \\
\text { mass }\end{array}$ & observed mass \\
\hline 1 & 6 & Ac- $N$ s 1 tbe- $N$ s 1 tbe- $N$ s 1 tbe- $N$ s 1 tbe- $N$ s 1 tbe $-N t \mathrm{Bu}-\mathrm{O} t \mathrm{Bu}$ & $96 \%$ & 934.74 & $935.75[\mathrm{M}+\mathrm{H}]^{+}$ \\
\hline 2 & 6 & Ac- $N$ s 1 tbe- $N$ s 1 tbe $-N$ s 1 tbe $-N$ s 1 tbe- $N t \mathrm{Bu}-N \mathrm{~s} 1$ tbe-O $t \mathrm{Bu}$ & $>95 \%$ & 934.74 & $935.75[\mathrm{M}+\mathrm{H}]^{+}$ \\
\hline 3 & 6 & Ac- $N$ s 1 tbe $-N$ s 1 tbe $-N$ s 1 tbe $-N t \mathrm{Bu}-N \mathrm{~s} 1$ tbe $-N \mathrm{~s} 1$ tbe- $O t \mathrm{Bu}$ & $97 \%$ & 934.74 & $935.75[\mathrm{M}+\mathrm{H}]^{+}$ \\
\hline 4 & 6 & Ac- $N$ s 1 tbe- $N$ s 1 tbe $-N t \mathrm{Bu}-N \mathrm{~s} 1$ tbe- $N$ s 1 tbe- $N$ s 1 tbe-O $t \mathrm{Bu}$ & $96 \%$ & 934.74 & $935.74[\mathrm{M}+\mathrm{H}]^{+}$ \\
\hline 5 & 6 & Ac- $N$ s 1 tbe- $N t$ Bu- $N$ s 1 tbe- $N$ s 1 tbe $-N$ s 1 tbe- $N$ s 1 tbe-O $t \mathrm{Bu}$ & $98 \%$ & 934.74 & $957.73[\mathrm{M}+\mathrm{Na}]^{+}$ \\
\hline 6 & 6 & Ac- $N t \mathrm{Bu}-N \mathrm{~s} 1$ tbe- $N$ s 1 tbe- $N$ s 1 tbe- $N$ s 1 tbe- $N$ s 1 tbe-O $t \mathrm{Bu}$ & $98 \%$ & 934.74 & $935.75[\mathrm{M}+\mathrm{H}]^{+}$ \\
\hline 7 & 6 & $\mathrm{Ac}-N t \mathrm{Bu}-N \mathrm{~s} 1$ tbe- $N t \mathrm{Bu}-N \mathrm{~s} 1$ tbe- $N t \mathrm{Bu}-N \mathrm{~s} 1$ tbe-OBn & $98 \%$ & 912.66 & $913.67[\mathrm{M}+\mathrm{H}]^{+}$ \\
\hline 8 & 6 & Ac- $N t \mathrm{Bu}-N$ s 1 tbe- $N t \mathrm{Bu}-N$ s 1 tbe- $N t \mathrm{Bu}-N$ s 1 tbe-OH & $96 \%$ & 822.62 & $823.62[\mathrm{M}+\mathrm{H}]^{+}$ \\
\hline 9 & 6 & $\mathrm{Ac}-N t \mathrm{Bu}-N t \mathrm{Bu}-N \mathrm{~s} 1$ tbe- $N$ s 1 tbe $N t \mathrm{Bu}-N t \mathrm{Bu}-\mathrm{O} t \mathrm{Bu}$ & $>99 \%$ & 850.65 & $851.65[\mathrm{M}+\mathrm{H}]^{+}$ \\
\hline 10 & 7 & $\mathrm{Ac}-N t \mathrm{Bu}-N t \mathrm{Bu}-N \mathrm{~s} 1$ tbe $-N \mathrm{~s} 1$ tbe $N$ s 1 tbe $N t \mathrm{Bu}-N t \mathrm{Bu}-\mathrm{O} t \mathrm{Bu}$ & $>97 \%$ & 991.77 & $\begin{array}{c}1014.75 \\
{[\mathrm{M}+\mathrm{Na}]^{+}}\end{array}$ \\
\hline 11 & 9 & $\begin{array}{r}\text { Ac- } N t \mathrm{Bu}-N t \mathrm{Bu}-N t \mathrm{Bu}-N \text { s1 tbe-Ns1tbe-Ns1tbe } N t \mathrm{Bu}-N t \mathrm{Bu}-N t \mathrm{Bu}- \\
\mathrm{O} t \mathrm{Bu}\end{array}$ & $95 \%$ & 1217.93 & $1218.93[\mathrm{M}+\mathrm{H}]^{+}$ \\
\hline 12 & 3 & Ac- $N t \mathrm{Bu}-N \mathrm{~s} 1$ tbe- $N \mathrm{~s} 1$ tbe $-\mathrm{O} t \mathrm{Bu}$ & $>99 \%$ & 511.40 & $512.40[\mathrm{M}+\mathrm{H}]^{+}$ \\
\hline 13 & 4 & Ac- $N$ s 1 tbe $-N t \mathrm{Bu}-N \mathrm{~s} 1$ tbe $-N$ s 1 tbe-O $t \mathrm{Bu}$ & $99 \%$ & 652.51 & $653.52[\mathrm{M}+\mathrm{H}]^{+}$ \\
\hline 14 & 5 & Ac- $N$ s 1 tbe $-N$ s 1 tbe $-N t \mathrm{Bu}-N \mathrm{~s} 1$ tbe- $N$ s 1 tbe $-\mathrm{O} t \mathrm{Bu}$ & $98 \%$ & 793.63 & $794.63[\mathrm{M}+\mathrm{H}]^{+}$ \\
\hline 15 & 6 & $\mathrm{Ac}-N t \mathrm{Bu}-N \mathrm{~s} 1$ tbe $-N \mathrm{~s} 1$ tbe $-N t \mathrm{Bu}-N \mathrm{~s} 1$ tbe $-N \mathrm{~s} 1$ tbe- $\mathrm{O} t \mathrm{Bu}$ & $>98 \%$ & 906.71 & $907.72[\mathrm{M}+\mathrm{H}]^{+}$ \\
\hline 16 & 9 & $\begin{array}{r}\text { Ac- } N t \mathrm{Bu}-N \mathrm{~s} 1 \text { tbe }-N \mathrm{~s} 1 \text { tbe }-N t \mathrm{Bu}-N \mathrm{~s} 1 \text { tbe }-N \mathrm{~s} 1 \text { tbe }-N t \mathrm{Bu}-N \mathrm{~s} 1 \text { tbe- } \\
N \mathrm{~s} 1 \text { tbe-O } t \mathrm{Bu}\end{array}$ & $>99 \%$ & 1302.03 & $1303.03[\mathrm{M}+\mathrm{H}]^{+}$ \\
\hline
\end{tabular}

${ }^{a}$ Number of residues

${ }^{\mathrm{b}}$ Determined by integration of the HPLC UV trace at $214 \mathrm{~nm}$.

\section{X-ray Studies for Peptoids 12 and 14.}

Crystals of trimer 12 and pentamer 14 suitable for X-ray crystallography were obtained by slow evaporation in ethyl acetate (Figure 2) and crystals of $\mathbf{1 2}$ were solved in the P1 space group and crystals of $\mathbf{1 4}$ were solved in the P2 2121 space group. The high resolution structures of trimer $\mathbf{1 2}$ and pentamer 14 complement the previously reported X-ray structures for $N t \mathrm{Bu}$ (dimer, trimer and pentamer) and $N$ s1 tbe (pentamer) homo-oligomers, and mixed $N t \mathrm{Bu} / N \mathrm{~s} 1$ tbe (compound $\mathbf{B}$, Table 3) oligomers. ${ }^{16,29,30}$ The dihedral angles for $\mathbf{1 2}$ and $\mathbf{1 4}$ are characteristic of the PPI-helical fold, primarily the $\omega$ values which are indicative of all-cis patterns. Some of the amide bonds display a significant distortion from planarity, especially the amide bond between residues 3 and 4 of $14(\omega=-24.7)$. The discrepancy between the $\varphi$ values of the $N t \mathrm{Bu}(\approx-90)$ and $N$ s1tbe 
monomers $(\approx-70)$ has already been noted (see Figure 1$).{ }^{16}$ The $\varphi$ torsion angle at the $C$-terminus of 14 is positive $(+80.7)$, the opposite of what is expected from the $S$ configuration. This may due to packing considerations together with the greater flexibility of the $C$-termini of peptoid chains. The difference of side-chains $\chi$ dihedral angles between the two types of monomers, has also been noted earlier (see Figure 1). ${ }^{16}$
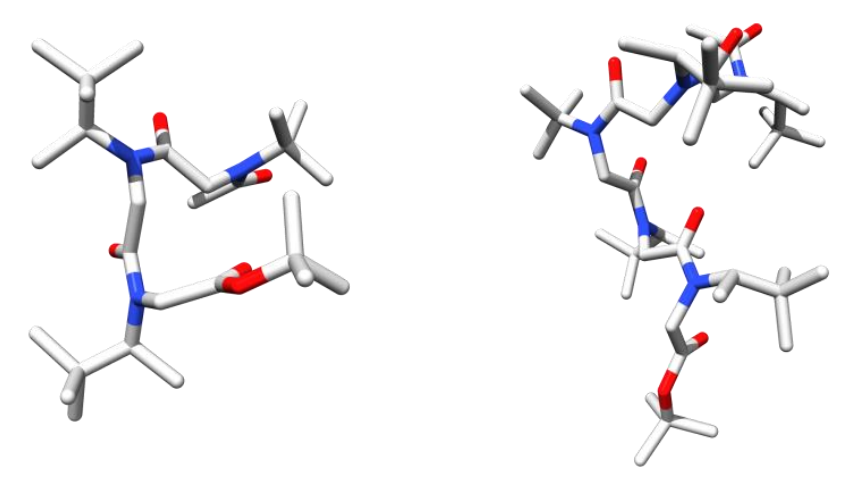

Figure 2. High resolution structures of peptoid trimer 12 (a) and pentamer $\mathbf{1 4}$ (b) as determined by X-ray crystallography.

Table 2. Observed torsion angles for peptoids 12 and 14 as determined by X-ray crystallography

\begin{tabular}{cccccc}
\hline Peptoid & residue & $\square$ & $\boldsymbol{\varphi}$ & $\square$ & $\square_{\mathbf{1}}$ \\
\hline $\mathbf{1 2}$ & $N t \mathrm{Bu}$ & 11.6 & -92.7 & -165.6 & -81.0 \\
& $N$ s1 tbe & -2.1 & -67.1 & 174.2 & -101.0 \\
& $N$ s1 tbe & -5.3 & -69.1 & - & -98.3 \\
\hline $\mathbf{1 4}$ & $N$ s1 tbe & -15.6 & -69.5 & -178.9 & -100.4 \\
& $N$ s1tbe & -11.3 & -71.7 & 173.4 & -100.0 \\
& $N t \mathrm{Bu}$ & -13.0 & -88.5 & -178.2 & -60.6 \\
& $N$ s1tbe & -24.7 & -71.2 & -161.7 & -105.1 \\
& $N$ s1tbe & -3.02 & 80.7 & - & -102.8 \\
\hline
\end{tabular}

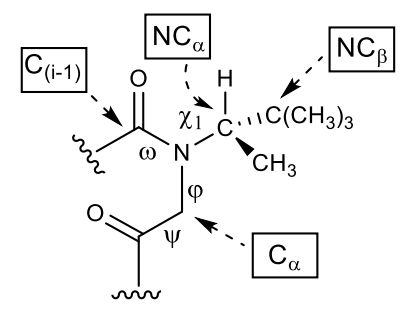

Dihedral angles definition: $\omega[\mathrm{C} \alpha(\mathrm{i}-1) ; \mathrm{C}(\mathrm{i}-1) ; \mathrm{N} ; \mathrm{C} \alpha], \varphi[\mathrm{C}(\mathrm{i}-1) ; \mathrm{N} ; \mathrm{C} \alpha ; \mathrm{C}], \psi[\mathrm{N} ; \mathrm{C} \alpha ; \mathrm{C} ; \mathrm{N}(\mathrm{i}+1)], \chi_{1}[\mathrm{C}(\mathrm{i}-1) ; \mathrm{N}$; $\mathrm{NC} \alpha ; \mathrm{NC} \beta]$

Overall backbone amide $\mathbf{K}_{\text {cis/trans }}$ values. Conformational control of a peptoid chain rests first on the individual control of its amide bonds geometry, i.e. cis or trans. The PPI-like conformation involves a continuous succession of cis-amide bonds. It has been established that $N t \mathrm{Bu}$ 
monomers do form cis-amide bonds with their preceding residue, independently of the oligomer length. We therefore focussed on the cis/trans isomerization of the $N$ s 1 tbe residues with their preceding units. For that purpose, we have looked at the $\mathrm{NC} \alpha$ methyne protons of the Nstbe residues, which display separate NMR chemical shifts in the cis and trans conformations (determined previously by COSY and NOESY NMR experiments). ${ }^{16}$ The methyne proton of the $N$ s 1 tbe is deshielded by approximately $1.0 \mathrm{ppm}$ in the cis conformation $(\approx 4.6 \mathrm{ppm})$ relative to the trans $(\approx 3.6 \mathrm{ppm})$, in accordance with reported data on both aromatic and aliphatic sidechains. ${ }^{15,26,28,42}$ The overall $K_{\text {cistrtrans }}$ values were determined in deuterated chloroform, acetonitrile, and methanol (for some representative compounds), by integration of the cis and trans methyne proton-carbon correlations of 2D-NMR HSQCAD experiments (Table 3). From this first series of values corresponding to the overall $K_{\text {cis/trans }}$ for the amide bonds between the $N$ s 1 tbe residues and their preceding residues, a second series of $K_{\text {cistrans }}$ values was calculated by including the $N t \mathrm{Bu}$-based amide linkages. For each sequence, the weighted average $K_{\text {cistrans }}$ were estimated taking a $K_{\text {cistrans }}$ of 32 for the $N t$ Bu monomers ( $97 \%$ of cis). 
Table 3. Peptoid Structure and Overall $K_{\text {cis/trans }}$ Values as determined by integration of HSQCAD NMR spectra in $\mathrm{CDCl}_{3}$ and $\mathrm{CD}_{3} \mathrm{CN}$

\begin{tabular}{|c|c|c|c|c|c|c|c|c|c|}
\hline \multirow[t]{2}{*}{ peptoid } & \multirow[t]{2}{*}{$l^{\mathrm{a}}$} & \multirow{2}{*}{$\begin{array}{l}\% \text { chiral } \\
\text { side } \\
\text { chains }\end{array}$} & \multirow[t]{2}{*}{$\begin{array}{l}\text { Monomer } \\
\text { sequence }^{b}\end{array}$} & \multicolumn{3}{|c|}{$\begin{array}{c}\text { weighted average of } K_{\text {cis/trans }} \\
(N \mathrm{~s} 1 \text { tbe residues })^{\mathrm{c}}\end{array}$} & \multicolumn{3}{|c|}{$\begin{array}{c}\text { weighted average of } \\
\mathrm{K}_{\text {cis/trans }} \\
\text { (all residues) }^{\mathrm{d}}\end{array}$} \\
\hline & & & & $\mathrm{CDCl}_{3}$ & $\mathrm{CD}_{3} \mathrm{CN}$ & $\mathrm{CD}_{3} \mathrm{OD}$ & $\mathrm{CDCl}_{3}$ & $\mathrm{CD}_{3} \mathrm{CN}$ & $\mathrm{CD}_{3} \mathrm{OD}$ \\
\hline 1 & 6 & 83 & $c-c-c-c-c-a$ & $>49.0^{\mathrm{e}}$ & $>49.0^{\mathrm{e}}$ & $>49.0^{\mathrm{e}}$ & $>49$ & $>49$ & $>49.0$ \\
\hline 2 & 6 & 83 & $c-c-c-c-a-c$ & 11.9 & 7.7 & & $>15.2$ & $>11.7$ & \\
\hline 3 & 6 & 83 & $c-c-c-a-c-c$ & 11.2 & 5.9 & & $>14.6$ & $>10.2$ & \\
\hline 4 & 6 & 83 & $c-c-a-c-c-c$ & 16.2 & 6.3 & & $>18.8$ & $>10.5$ & \\
\hline 5 & 6 & 83 & $c-a-c-c-c-c$ & 11.0 & 7.8 & & $>14.5$ & $>11.8$ & \\
\hline 6 & 6 & 83 & $a-c-c-c-c-c$ & 18.0 & 9.7 & 29.5 & $>20.3$ & $>13.4$ & 32.7 \\
\hline 7 & 6 & 50 & $a-c-a-c-a-c$ & 2.0 & 1.7 & & $>17.0$ & $>16.8$ & \\
\hline 8 & 6 & 50 & $a-c-a-c-a-c$ & - & - & & - & - & \\
\hline $\mathbf{A}^{16}$ & 6 & 66 & $a-c-c-c-c-a$ & $>19.0$ & $>19.0$ & & $>23.3$ & $>23.3$ & \\
\hline $\mathbf{B}^{16}$ & 8 & 50 & $a-a-c-c-c-c-a-a$ & $>19.0$ & $>19.0$ & & $>25.5$ & $>25.5$ & \\
\hline 9 & 6 & 33 & $a-a-c-c-a-a$ & 23.5 & 19.5 & 33.3 & $>29.1$ & $>27.8$ & 43.7 \\
\hline 10 & 7 & 43 & $a-a-c-c-c-a-a$ & $>49.0^{\mathrm{e}}$ & 32.8 & & $>49$ & $>42.0$ & \\
\hline 11 & 9 & 33 & $a-a-a-c-c-c-a-a-a$ & $>49.0^{\mathrm{e}}$ & $>49.0$ & & $>49.0$ & $>49.0$ & \\
\hline 12 & 3 & 66 & $a-c-c$ & 2.4 & - & & $>12.2$ & - & \\
\hline 13 & 4 & 75 & $c-a-c-c$ & 2.0 & - & & $>9.5$ & - & \\
\hline 14 & 5 & 80 & $c-c-a-c-c$ & 3.6 & 7.7 & & $>9.3$ & $>12.5$ & \\
\hline 15 & 6 & 66 & $a-c-c-a-c-c$ & 12.3 & 6.8 & 19.6 & $>18.8$ & $>15.2$ & 29.4 \\
\hline 16 & 9 & 66 & $a-c-c-a-c-c-a-c-c$ & 4.2 & 15.0 & 15.9 & $>13.4$ & $>20.6$ & 26.9 \\
\hline
\end{tabular}

${ }^{a}$ Number of residues

'The achiral $N t \mathrm{Bu}$ monomers are represented by the letter "a" and the chiral Ns1 tbe by "c"

${ }^{c}$ Determined for the amide bonds between $N$ s 1 tbe residues and their preceding residues

${ }^{\mathrm{d}}$ Determined for all the residues, considering that the $N t \mathrm{Bu}$ monomers form exclusively cis-amide bonds with their preceding $(i-1)$ residues. Calculation was made with $K_{\text {cis } / \text { trans }}=32$ for the $N t \mathrm{Bu}$ monomers $(97 \%$ of cis)

${ }^{\mathrm{e}}$ Trans rotamers were not detected.

Acetonitrile has been commonly used in structural studies of peptoids, notably those with $\alpha$ chiral aromatic side chains which were found to adopt the all-cis PPI helix conformation. Acetonitrile is recognized to minimize interamide $n \rightarrow \pi^{*}=0$ interactions within peptoid, thereby destabilizing the trans amide conformation. ${ }^{26}$ Furthermore, determination of the cis/trans ratio of the $N$-terminal acetamide of diamide peptoid model systems, expected to reproduce the behavior of larger peptoid oligomers, indicates that the fraction of cis isomer is generally higher in acetonitrile than in methanol or chloroform, at least for uncharged side chains. ${ }^{26}$ This trend is not verified for the peptoids 1-16 (Table 3). Indeed, with the exception of peptoids $\mathbf{1 4}$ and 16, the fraction of cis isomer is higher in non-polar $\mathrm{CDCl}_{3}$ than in $\mathrm{CD}_{3} \mathrm{CN}$, and is even higher in $d_{4}$ methanol, as seen from the ${ }^{\mathrm{CD}_{3} \mathrm{OD}} K_{\text {cis/trans }}$ determined for the representative compounds $\mathbf{1 , 6}, \mathbf{9}, 15$ and $\mathbf{1 6}$ for which the trans rotamers are completely or largely suppressed. Also of note from the comparison of the overall $K_{c i s / t r a n s}$ for compounds 1-6 is that the positioning of a single cisenforcing $N t \mathrm{Bu}$ monomer at the carboxy terminus proves exceptionally efficient to suppress the 
trans-amide rotamers. This is consistent with the finding that the carboxy terminus of the PPI peptoid helix is structurally less stable than the amino terminus. ${ }^{36}$ Although the cis/trans isomerization of the backbone tertiary amides is totally suppressed in the case of peptoid $\mathbf{1}$, its ${ }^{1} \mathrm{H}$ NMR spectrum $\left(\mathrm{CDCl}_{3}\right)$ showed a very small amount of residual conformational heterogeneity, evidenced for example on the $\mathrm{CO}_{2} t \mathrm{Bu}$ resonance, which is no longer present in $d_{4}$-methanol. There is also evidence that the peptoids containing a central chiral segment of 2 to $4 \mathrm{Ns} 1$ tbe consecutive residues, surrounded by $N t$ Bu residues display the higher overall $K_{\text {cis/trans }}$ (A, B, 911). In contrast, the incorporation of $N t \mathrm{Bu}$ monomers every two $N$ s1tbe residues (12-16) does not ensure the complete suppression of the peptoid amide cis-trans rotameric isomerism.

Circular dichroism of hexamers 1-6. The CD spectra of oligomers 1-6 are shown in Figure 3. All the CD curves are well-defined and display the spectral features that are typically associated to the polyproline type I helix of peptoids substituted with aliphatic side-chains, i.e., two minima at $190 \mathrm{~nm}$ and $225 \mathrm{~nm}$, and a positive maximum around $210 \mathrm{~nm} \cdot{ }^{14} \mathrm{In}$ acetonitrile, compound $\mathbf{1}$ with the $N t \mathrm{Bu}$ monomer positioned at the $C$-terminus displays the more intense ellipticity on a per-residue molar basis (MRE = 11741 at 208 nm, Figure 3a and Figure S2), at a high level comparable to that of the nonamer Ac- $(N s 1$ tbe $){ }_{9}-\mathrm{O} t \mathrm{Bu}(\mathrm{MRE}=12673,210 \mathrm{~nm}) .{ }^{16}$ By contrast, hexamers 5 and $\mathbf{6}$ with the $N t \mathrm{Bu}$ residues located at the $2^{\text {nd }}$ and first position of the sequence (from $\mathrm{N}$ to $\mathrm{C}$ ), display lower ellipticities (MRE $=4324$ for 6 at $208 \mathrm{~nm}$ ), of the same order of magnitude as that of the homo-pentamer Ac-(Ns1tbe) ${ }_{5}-\mathrm{O} t \mathrm{Bu}(\mathrm{MRE}=4967$ at $208 \mathrm{~nm}){ }^{16}$ Compounds 2, 3 and 4, form a homogeneous group whose ellipticity at $208 \mathrm{~nm}$ (in the range 6100-6900) is intermediate those of compound $\mathbf{1}$ and 5/6. On the whole, there appears to be a trend toward ellipticity decreasing with increasing remoteness of the $N t \mathrm{Bu}$ monomer from the carboxy terminus. This was further verified in $\mathrm{MeOH}$, in which the spectral intensity at $208 \mathrm{~nm}$ consistently decreases when the $N t \mathrm{Bu}$ unit moves away from the carboxy terminus (Figure $3 \mathrm{~b}$ and 4). The strongest CD intensity of hexamer $\mathbf{1}$ within the group of peptoids 1-6 is consistent with an all cis-amide backbone ( $K_{\text {cistrans }}>49$ in deuterated chloroform, acetonitrile and methanol, Table 3). The ${ }^{\mathrm{CD}_{3} \mathrm{CN}} K_{\text {cistrans }}$ values between 10.2 and 13.4 for hexamers 2-6 are indicative of a remaining backbone amide conformational heterogeneity (trans rotamers populated at 7-9\%), comparable to that of the peptoid hexamer Ac- $(N \mathrm{~s} 1 \text { tbe })_{6}-\mathrm{O} t \mathrm{Bu}\left({ }^{\mathrm{CD}_{3} \mathrm{CN}} K_{\text {cis/trans }}=10.4\right) .{ }^{16} \mathrm{An}$ increase of ellipticity (compound 2) and a decrease (compound 6) are observed by switching the solvent from acetonitrile to methanol, but more generally, this first series of peptoids is not much affected by solvent polarity, which is consistent with the fact that the conformation is primarily governed by steric interactions. ${ }^{15}$ This is in contrast with the CD spectra of the Ns1tbe 
homooligomers which were decreased in methanol relative to those in acetonitrile. ${ }^{16}$ This suggests that the presence of a single bulky $N t \mathrm{Bu}$ residue within the peptoid sequence may already have a positive effect on the conformational stability.
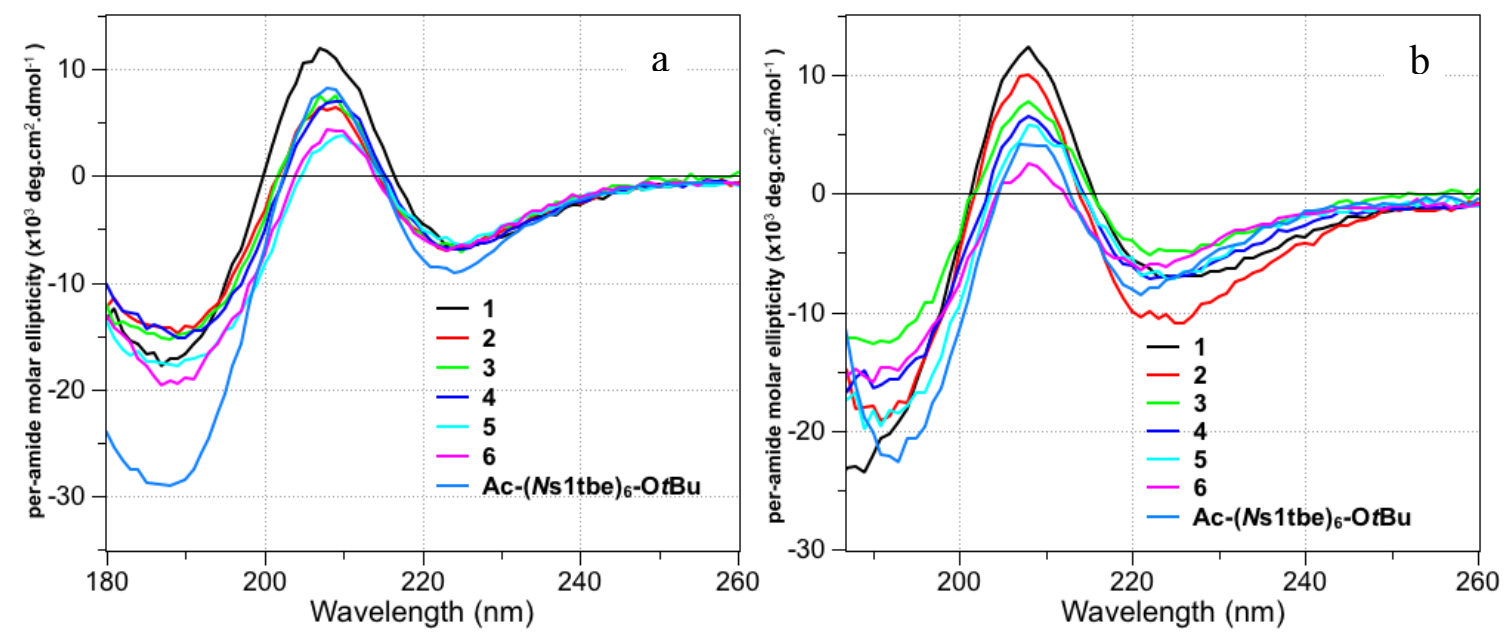

Figure 3. CD spectra of hexamers 1-6 and reference compound Ac-(Ns1tbe) 6 in acetonitrile (a) and methanol (b).

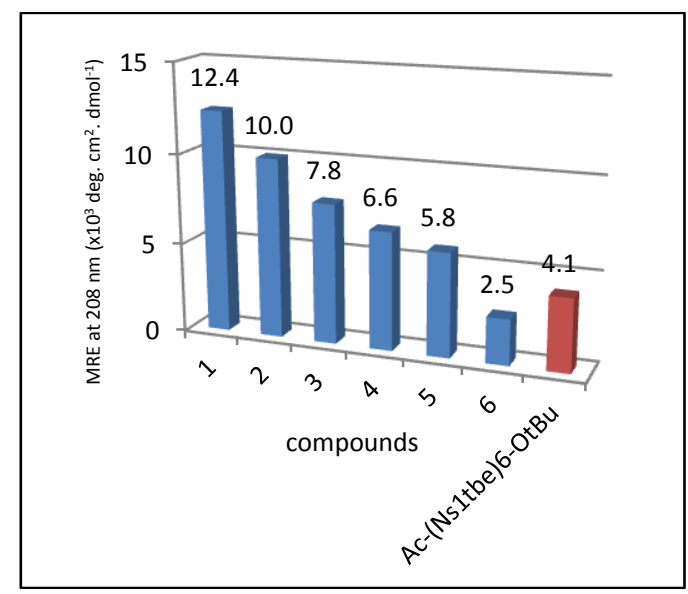

Figure 4. MRE values of hexamers 1-6 and reference compound Ac-(Ns1tbe $)_{6}$ at $208 \mathrm{~nm}$ in $\mathrm{MeOH}$

Of note, is the significant difference between the intensity of the negative band at $190 \mathrm{~nm}$ between the homo-oligomer Ac-(Ns1tbe) $)_{6}-\mathrm{O} t \mathrm{Bu}$ and the hexamers 1-6. For hexamers 1-6, the negative band at $190 \mathrm{~nm}$ also tends to increase with the decrease of the positive band at $210 \mathrm{~nm}$. Interestingly, the CD curves of hexamers $\mathbf{1}$ (c-c-c-c-c-a) and $\mathbf{A}$ (a-c-c-c-c-a) in acetonitrile and methanol are virtually superposable (Figure 5), which in the light of the previous results, show that within this group of peptoids, a single $N t \mathrm{Bu}$ monomer strategically positioned at the $C$ terminus is sufficient to achieve a robust helical structure. Also of note is that, once a first $N t \mathrm{Bu}$ is positioned at the $C$-terminus, a second mutation of a chiral $N$ s1tbe monomer by a $N t \mathrm{Bu}$ at the $\mathrm{N}$-terminus is not detrimental to peptoid helicity, albeit a decrease of the amount of chiral side- 
chains from $83 \%$ (1) to $66 \%$ (A). "Ends effects" have been observed previously in the study of peptoids and retropeptoids composed of aromatic chiral and achiral monomers. ${ }^{36}$ It has been shown, for example, that placing a bulky chiral Nrpe monomer on the carboxy terminus rather than on the amino terminus dramatically increased CD intensity.
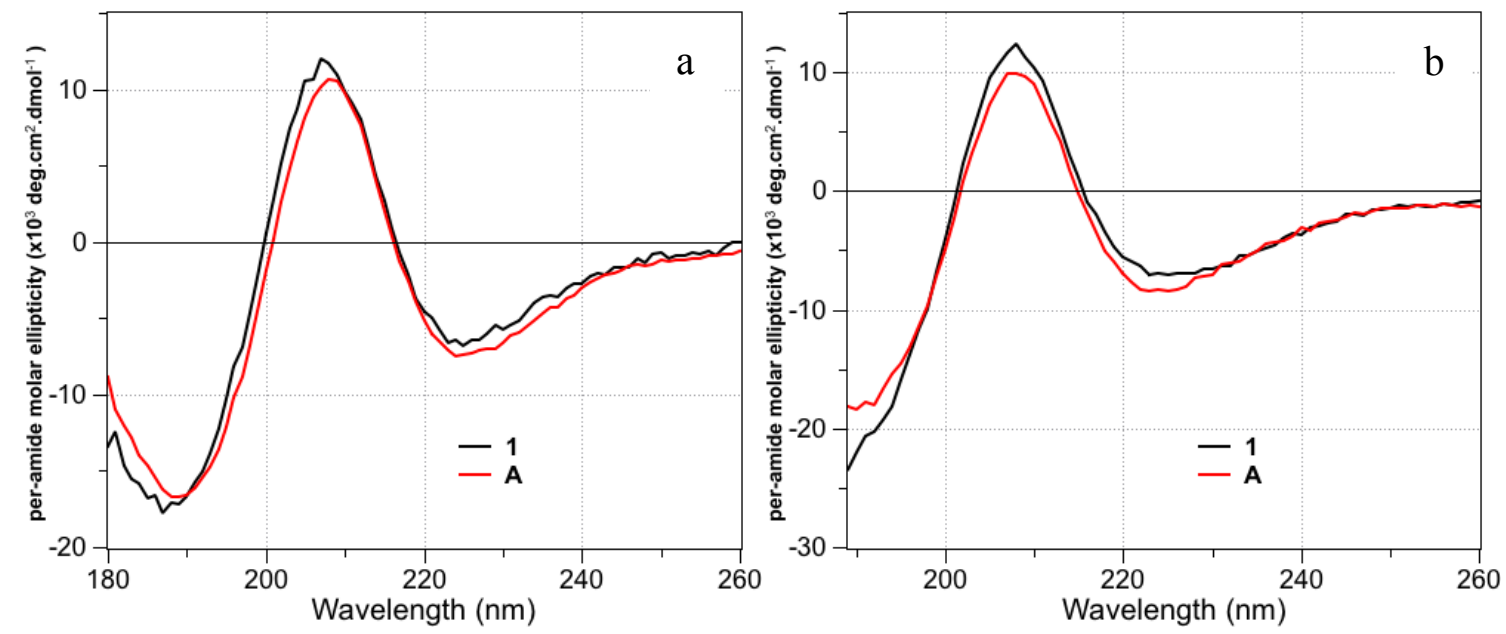

Figure 5. CD spectra of hexamers 1 and $\mathbf{A}$ in acetonitrile (a) and methanol (b).

\section{Circular dichroism of hexamers 7-11.}

The $\mathrm{CD}$ spectra of the alternated $(N t \mathrm{Bu}-N \mathrm{~s} 1 \text { tbe })_{3}$ hexamer $\mathbf{7}$ and its corresponding free carboxy acid $\mathbf{8}$ are shown in figures S3-S5. The hexamer 7 is better structured in methanol than in acetonitrile with a MRE value at $208 \mathrm{~nm}$ in methanol nearly twice that in acetonitrile. The CD spectrum of $\mathbf{7}$ in $\mathrm{MeOH}$ is close to those of hexamers $\mathbf{A}$ and $\mathbf{1 5}$ in shape and intensity (Figure S4). In contrast, a significant decrease of helical fold was observed for the free acid hexamer $\mathbf{8}$, notably in acetonitrile and acetonitrile/aqueous buffer solutions, as compared to the ellipticity in methanol (Figure S5).

All three compounds 9-11 are characterized by a central chiral portion ( 2 or $3 \mathrm{Ns} 1$ the residues), flanked on both ends by achiral segments of same length ( 2 or $3 \mathrm{NtBu}$ residues). Their $\mathrm{CD}$ curves were compared to those of the reference compounds A and $\mathbf{B}$ (Figure 6). The CD curves of peptoids 9-11 in acetonitrile show a profile similar to those of compounds $\mathbf{A}$ and $\mathbf{B}$, albeit with reduced intensities of the maxima. The positive band of peptoids $\mathbf{9}$ and $\mathbf{1 1}(211 \mathrm{~nm})$ is blue shifted by $3 \mathrm{~nm}$ relative to that of peptoid A $(208 \mathrm{~nm})$, which seems to be in line with their smaller chiral content. (33\% for $\mathbf{9}$ and $\mathbf{1 1}$ vs 66\% for A, Tables 2). The decline in the ellipticity of peptoids 9-11 relative to $\mathbf{A}$ in acetonitrile, as estimated in the region of the spectra at around $210 \mathrm{~nm}$, is more pronounced for the nonamer $11(-43 \%)$, than for the heptamer $\mathbf{1 0}(-31 \%)$ and the hexamer $9(-26 \%)$. We find that in methanol; more intense CD spectra are obtained, 
indicating a more robust helical fold. The oligomers $\mathbf{9}$ and $\mathbf{1 1}$ display the strongest intensities $\left(\mathrm{MRE}_{209 \mathrm{~nm}}>12000\right)$, after the octamer $\mathbf{B}\left(\mathrm{MRE}_{209 \mathrm{~nm}}=15000\right)$. It is premature to establish a relationship between the monomer composition of this sub-family of peptoids $(\mathbf{9 - 1 1}, \mathbf{A}$ and $\mathbf{B})$ and their conformational properties, but some notable observations can be made. In both solvents, the intensity of the negative band at $190 \mathrm{~nm}$ increases with the increase of proportion of s1tbe chiral side-chains (SI, Table S2), suggesting a contribution from coupling interactions between the s1tbe side chains and backbone groups. Also, the per-residue molar ellipticity of peptoid 9 (a-a-c-c-a-a) is remarkable, considering its short length and low percentage of chiral side chains (33\%). The MRE intensity of peptoid 9 at $208 \mathrm{~nm}$ is at the same level as that of hexamer 1, which has $83 \%$ of chiral side-chains (SI, Figure S6). In addition, the CD spectrum of hexamer 9 in methanol has comparable shape and intensity to that of the nonamer 11 (a-a-a-c-cc-a-a-a), also composed of only $33 \%$ of chiral residues. This is the first time that peptoids composed of just one-third $\alpha$-chiral side chains give a stronger $\mathrm{CD}$ signal than their parent peptoid comprising only chiral side chains.

The few compounds studied here owning the generic sequence $(a)_{x}(c)_{y}(a)_{x}$ with (a) and (c) corresponding to the achiral $N t \mathrm{Bu}$ and chiral $N$ s1tbe monomers, respectively, show that this design principle is advantageous to achieve a stable helical folding with a low content of chiral side chains. The central segment in the oligomers studied is able to transfer its chirality with great efficacy to both ends of the oligomers.
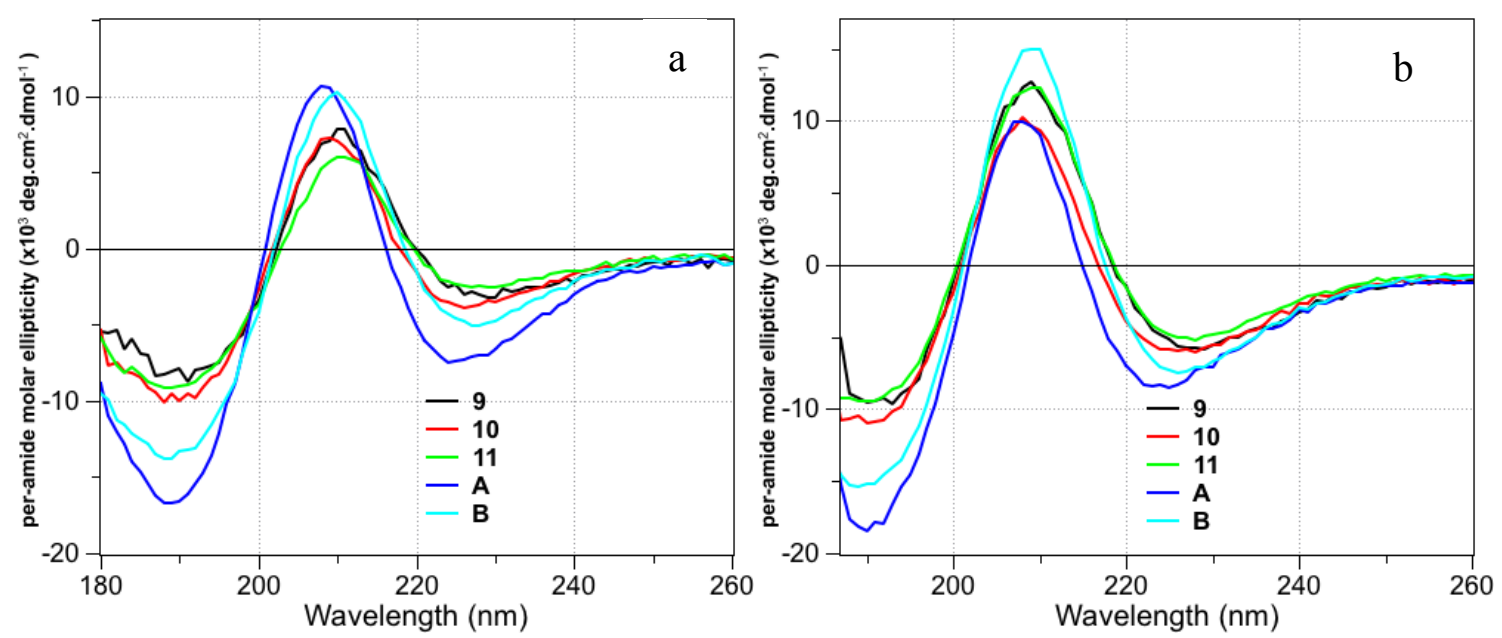

Figure 6. CD spectra of peptoids 9-11, $\mathbf{A}$ and $\mathbf{B}$ in acetonitrile (a) and methanol (b).

\section{Circular dichroism of peptoids 12-16.}

Characterization of peptoids 12-16 by CD shows that the minimum chain length to obtain the characteristic helix-like profile is the pentamer length (14) (Figure 7). Indeed, trimers 12 and tetramers 13 show no helical structure by CD (Figure 7 and 8). The CD spectra of pentamer 14 
and hexamer 15 show that the signal intensity increases with increasing the length by one residue. In contrast, comparison of spectra for hexamer 15 (a-c-c) $)_{2}$ and nonamer 16 (a-c-c $)_{3}$ in acetonitrile and methanol shows that the intensity at $\approx 210 \mathrm{~nm}$ does not increase with the oligomer length. The positive band of $\mathbf{1 6}$ is even slightly diminished (and red-shifted by $3 \mathrm{~nm}$ ) relative to 15 (Figure 7), despite the fact that the overall backbone amide cis:trans ratio is higher for $16\left({ }^{\mathrm{CD}_{3} \mathrm{CN}} K_{\text {cis/trans }}=20.6\right)$ than for $15\left({ }^{\mathrm{CD}_{3} \mathrm{CN}} K_{\text {cis/trans }}=15.2\right)$. These observations suggest that the $(\mathrm{a}-\mathrm{c}-\mathrm{c})_{n}$ sequence design does not allow for an optimal propagation of the chiral secondary structure.
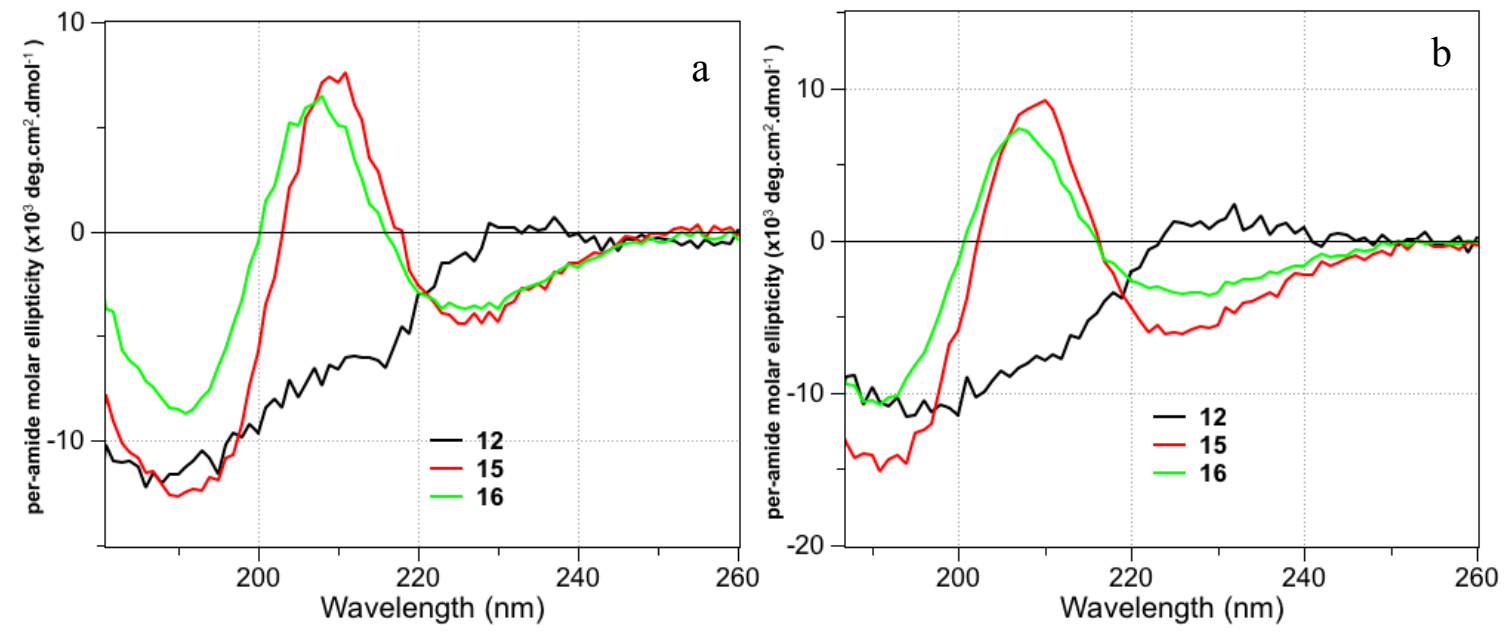

Figure 7. CD spectra of peptoids $\mathbf{1 2}, \mathbf{1 5}$ and $\mathbf{1 6}$ corresponding to (a-c-c) $)_{n}(n=1,2,3)$, in acetonitrile (a) and methanol (b).
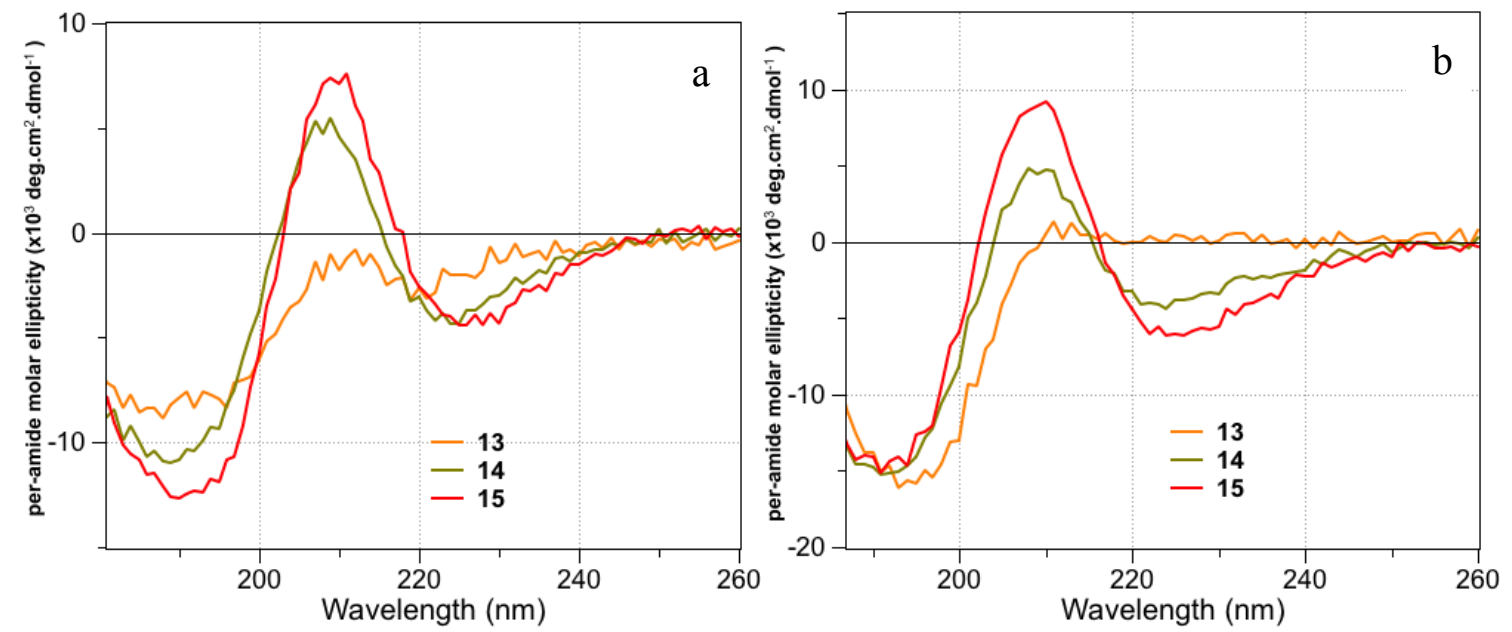

Figure 8. CD spectra of peptoids 13 (c-a-c-c), 14 (c-c-a-c-c) and 15 (a-c-c-a-c-c), in acetonitrile (a) and methanol

\section{Temperature study of compound 16}

(b).

Previously, we demonstrated the thermal conformational stability of the PPI-like helix of the homo-nonamer $\mathrm{Ac}-(\mathrm{Ns} 1 \mathrm{tbe})_{9}-\mathrm{O} t \mathrm{Bu}{ }^{16}$ In contrast, the degree of helical fold significantly decreased upon heating the solution of the nonamer 16, AcO- $(N t \mathrm{Bu}-N \mathrm{~s} 1 \text { tbe- } N \mathrm{~s} 1 \text { tbe })_{3}-\mathrm{O} t \mathrm{Bu}$, in 
acetonitrile from 15 to $75{ }^{\circ} \mathrm{C}$, demonstrating the lesser thermal stability of $N$ sltbe-based peptoid sequences incorporating $N t \mathrm{Bu}$ monomers at every two residues (SI, Figure S7). Nevertheless, when the sample was cooled back to $15^{\circ} \mathrm{C}$, reversibility took place, giving back a CD spectrum of same shape and intensity than at start (SI, Figure S8). The helical folding sensitivity of the nonamer 16 to an increase of temperature was also examined by NMR by measuring the average $K_{\text {cistrans }}$ for the $N$ s1 tbe units within the peptoid backbone at various temperatures $\left(\mathrm{CD}_{3} \mathrm{CN}, 15-75\right.$ ${ }^{\circ} \mathrm{C}$ ) (Table S3). We observed a gradually decrease in ${ }^{\mathrm{AVG}} K_{\text {cistrans }}$ with increasing the temperature, going from a value of 18.3 at $15{ }^{\circ} \mathrm{C}\left(95 \%\right.$ of cis rotamer) to 2.1 at $75{ }^{\circ} \mathrm{C}(68 \%$ of cis rotamer). We therefore confirm that the decrease of helical folding upon elevating the temperature can be essentially ascribed to the increase of cis/trans rotameric heterogeneity.

In summary, we investigated the effect of site-specific placement of $\mathrm{Nt} \mathrm{Bu}$ cis-inducer monomer on the helical secondary structure of $N$ s1tbe-based sequences. The synthesized oligomers 1-16 comprising exclusively aliphatic side-chains, chain lengths between 3 and 9 residues, of which ten are hexamers, and percentages of chiral monomers ranging from 33 to $83 \%$ were analyzed by NMR, CD spectroscopy and X-ray diffraction for two of them. The degree of helical fold was estimated by CD at around $210 \mathrm{~nm}$ which corresponds to the more relevant signal for the PPIlike helix of peptoids carrying aliphatic side-chains. Switching the solvent from acetonitrile to methanol increased the fraction of cis isomer as seen from the NMR of the representative peptoids 1, 6, 9, 15 and 16. This observation is commensurate with the CD spectra of the peptoids in methanol which are either identical or greater in intensity as compared to those observed in acetonitrile. At this time no correlation can be found between the intensity of the negative band at $190 \mathrm{~nm}$ and the monomer composition of the peptoids. It is noteworthy that the CD spectrum of the short length tetramer 13 only displays this negative band around $190 \mathrm{~nm}$. A single mutation of each of the six $N$ s1 tbe residues of homo-oligomer ( $N \mathrm{~s} 1$ tbe $)_{6}$ to $N t \mathrm{Bu}$ residue (hexamers 1-6) was used to probe the influence of the positioning of a single achiral $t \mathrm{Bu}$ side chain on the helical structure. We show that a single $N t \mathrm{Bu}$ monomer at the carboxy terminus enables to completely suppress the backbone trans-amide rotamers and consequently reinforce the helical fold of peptoid hexamers. This finding is consistent with the fact that the carboxy terminus of the peptoid helix is recognized to be less structurally stable than the amino terminus. ${ }^{36}$ We anticipate that this favorable C-terminal stabilizing "end effect" might also operate in longer peptoids, including oligomers carrying aromatic side chains. Of the ten hexamer sequences studied, peptoid 9 consisting of two central Ns1 tbe residues flanked at both ends by two $\mathrm{N} t \mathrm{Bu}$ residues revealed a remarkable helical folding, especially in methanol, in view 
of its rather short length and low content of chiral sides chains (33\%). Overall, the sequence design consisting of a central chiral segment flanked by achiral parts (9-11) permits an efficient helical chirality transfer to the peptoid extremities. In contrast, the incorporation of $N t \mathrm{Bu}$ monomers every two residues, thus forming an achiral helix face, results in a slight decrease of helicity. Our finding will be useful to reinforce the stability of organosoluble peptoid helices aimed at interacting with a biological hydrophobic environment such as phospholipidic membranes. Work is now in progress to extend the scope of our finding to peptoids incorporating chiral aromatic monomers, hydrosoluble monomers and functional monomers.

\section{EXPERIMENTAL SECTION}

General methods. THF, $\mathrm{CH}_{2} \mathrm{Cl}_{2}$ were dried over aluminum oxide via a solvent purification system. EtOAc, $\mathrm{CH}_{2} \mathrm{Cl}_{2}$, cyclohexane, and $\mathrm{MeOH}$ for column chromatography were obtained from commercial sources and were used as received. All other solvents and chemicals obtained from commercial sources were used as received. Melting points were determined on a Stuart Scientific SMP3 microscope apparatus and are uncorrected. NMR spectra were recorded on a $400 \mathrm{MHz}$ Bruker Avance III HD spectrometer or a $500 \mathrm{MHz}$ Bruker AC-500 spectrometer. Chemical shifts are referenced to the residual solvent peak and $J$ values are given in hertz. The following multiplicity abbreviations are used: (s) singlet, (ls) large singlet, (d) doublet, (t) triplet, (q) quartet, (m) massif, and (br) broad. Where applicable, assignments were based on COSY, HMBC, HSQC, and ${ }^{13}$ Cexperiments. TLC was performed on Merck TLC aluminum sheets, silicagel $60, \mathrm{~F}_{254}$. Progression of reactions was, when applicable, followed by TLC. Visualizing of spots was effected with UV-light and/or vanillin in $\mathrm{EtOH} / \mathrm{H}_{2} \mathrm{SO}_{4}$. Flash chromatography was performed with Merck silica gel 60, 40-63 $\mu \mathrm{m}$. HRMS was recorded on a Micromass Q-Tof Micro (3000 V) apparatus or a Q Exactive Quadrupole-Orbitrap Mass Spectrometer. LC-MS was recorded a Q Exactive Quadrupole-Orbitrap mass spectrometer coupled to a UPLC Ultimate 3000 (Kinetex EVO C18; $1.7 \mu \mathrm{m} ; 100 \mathrm{~mm} \times 2.1 \mathrm{~mm}$ column with a flow rate of $0.45 \mathrm{~mL} \mathrm{~min}-1$ with the following gradient: a linear gradient of solvent B from 5\% to $95 \%$ over $7.5 \mathrm{~min}$ (solvent $\mathrm{A}=\mathrm{H}_{2} \mathrm{O}+0.1 \%$ formic acid, solvent $\mathrm{B}=$ acetonitrile $+0.1 \%$ formic acid) equipped with a DAD UV/vis 3000 RS detector. HPLC analysis was performed on a Dionex instrument equipped with an Uptisphere (ODB, $5 \mu \mathrm{m}, 120 \AA$, $4.6 \times 250 \mathrm{~mm}$ ) and a Dionex UVD 340 detector. X-ray data were collected at $100 \mathrm{~K}$ with an Oxford Diffraction Xcalibur 2 diffractometer equipped with a copper microsource $(\lambda=1.5418 \AA)$.

NMR experiments. A Bruker Avance III HD 500 spectrometer operating at $500.13 \mathrm{MHz}$ for ${ }^{1} \mathrm{H}$ and $125.77 \mathrm{MHz}$ for ${ }^{13} \mathrm{C}$ with a $5 \mathrm{~mm}$ pulsed-field z-gradient TXI probe was used. For each 
sample, the probe was carefully tuned, and all normal and adiabatic pulses were well calibrated. For each 2D heteronuclear ${ }^{1} \mathrm{H} /{ }^{13} \mathrm{C}$ HSQCAD (Bruker sequence: hsqcedetgpsisp2.3) experiments were performed with quadrature phase detection in dimensions, using Echo-Antiecho detection mode in the indirect one. For each 768 increments in the indirect dimension, $2 \mathrm{~K}$ data points were collected and 8 transients were accumulated in the direct dimension. Adiabatic ${ }^{13} \mathrm{C}$ decoupling (Bruker sequence : bi_p5m4sp_4sp.2) was performed during acquisition. The spectral widths (SW) were fixed to $8 \mathrm{ppm}$ for ${ }^{1} \mathrm{H}$ and to $165 \mathrm{ppm}$ for ${ }^{13} \mathrm{C}$. A $\pi / 2$ shifted square sine-bell function was applied in the two dimensions before Fourier transformation. Spectra were acquired and treated with Bruker Topspin version 3.5pl5 and referenced to solvent. All NMR spectra were recorded at $298 \mathrm{~K}$.

Circular Dichroism Spectroscopy in the far-UV range. Peptoid stock solutions were prepared by dissolving at least $2 \mathrm{mg}$ of each peptoid, weighed using a high-precision balance (Sartorius), in spectroscopic grade acetonitrile or methanol. The stock solutions then were diluted with spectroscopic grade solvent to the concentration of $500 \mu \mathrm{M}$. CD experiments were carried out in a Chirascan-plus spectropolarimeter equipped with a Peltier system (Applied Photophysics Ltd, Surrey, UK). CD spectra were obtained in a flat quartz cell (path length $0.01 \mathrm{~cm}$ ) at $293^{\circ} \mathrm{K}$ using a scan rate of $0.5 \mathrm{~nm} / \mathrm{sec}$, in the far-UV range $(180$ to $260 \mathrm{~nm})$ and are the average of three successive measurements. The spectrum of a solvent blank was subtracted from the raw CD data, and the resulting data were expressed in terms of per-amide molar ellipticity $\left(\mathrm{deg} \cdot \mathrm{cm}^{2} \cdot \mathrm{dmol}^{-1}\right)$, as calculated per mole of amide groups present and normalized by the molar concentration of peptoid.

\section{General procedure for the solution-phase synthesis of peptoids 1-16 by the submonomer} protocol. tert-Butyl bromoacetate was used as starting material for all synthesized compounds with the exception of the synthesis of hexamers $\mathbf{7}$ and $\mathbf{8}$ for which benzyl bromoacetate was used. The commercially available primary amines tert-butylamine or the (2S)-3,3-dimethylbutan2-amine (sltbe amine) were employed for the substitution steps. The bromoacetamide compounds were purified by flash silica gel chromatography prior to their reaction with the submonomer primary amine building blocks

General procedure A: Submonomer bromine atom substitution with primary amines. To a solution of tert-butyl bromoacetate (or benzyl bromoacetate for the synthesis of peptoid 7) or crude bromoacetyl amide (1.0 equiv, $0.2 \mathrm{M}$ ) in EtOAc or THF at rt was added $\mathrm{Et}_{3} \mathrm{~N}$ (2.0 equiv.) followed by the chosen primary amine (4.0 equiv.). After stirring overnight at room temperature, the resulting mixture was diluted with EtOAc $(10 \mathrm{~mL}$ per mmol of starting material) and filtered, washing the solids with EtOAc. The filtrate was then concentrated under reduced pressure. 
EtOAc was added to the residue which was then concentrated under reduced pressure. This was repeated twice and the residue was dried in vacuo, yielding the desired crude secondary amine which was used in the next step without further purification.

General procedure B: Submonomer bromoacetylation. To a solution of the crude secondary amine (1.0 equiv, $0.2 \mathrm{M}$ ) in dry THF (or EtOAc) at $-10^{\circ} \mathrm{C}$ under argon was added $\mathrm{Et}_{3} \mathrm{~N}$ (1.2 equiv.) and then bromoacetyl bromide (1.05 equiv.). After stirring for $1 \mathrm{~h}$ at $-10^{\circ} \mathrm{C}$ the resulting mixture was diluted with EtOAc $(10 \mathrm{~mL}$ per mmol of starting material) and the salts were filtered, washing the solid with EtOAc. The filtrate was then concentrated in vacuo, yielding the crude bromoacetyl amide which was purified by flash column chromatography on silica gel.

General procedure $C$ : terminal $N$-acetylation. To a solution of a peptoid (1 equiv.) and $\mathrm{Et}_{3} \mathrm{~N}$ (1.4 equiv.) in dry $\operatorname{EtOAc}(0.2 \mathrm{M})$ at $0^{\circ} \mathrm{C}$ under $\mathrm{Ar}$, was added dropwise $\mathrm{AcCl}$ (1.2 equiv.) and the reaction mixture was stirred overnight at room temperature. The mixture was filtered, and the solids washed with EtOAc. The filtrate was then concentrated in vacuo, yielding the crude Nterminal acetylated compound which was purified by flash column chromatography on silica gel

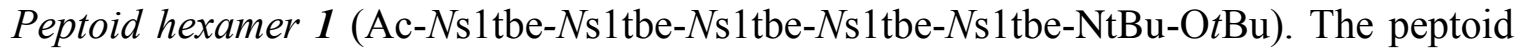
1 was synthesized in 12 steps from tert-butyl bromoacetate $(390 \mathrm{mg}, 2.0 \mathrm{mmol})$ according to procedures $\mathrm{A}$ and $\mathrm{B}$ for the submonomer elongation steps and procedure $\mathrm{C}$ for the final $\mathrm{N}$ terminal acetylation. Peptoid $\mathbf{1}$ was isolated as a white solid after purification by flash column chromatography on silica gel. (89 mg, $0.095 \mathrm{mmol})$; $\mathrm{R}_{f}=0.54$ (100\% EtOAc). m.p. 227.5-228.5 ${ }^{\circ} \mathrm{C}$ HRMS (TOF MS ES+) $m / z$ calcd for $\mathrm{C}_{52} \mathrm{H}_{99} \mathrm{~N}_{6} \mathrm{O}_{8}[\mathrm{M}+\mathrm{H}]^{+}$935.7518; found 935.7525 . Analytical HPLC purity $96 \%$.

${ }^{1} \mathrm{H}$ NMR (400 MHz, $\left.\mathrm{CDCl}_{3}\right) \delta(\mathrm{ppm}): 0.82-1.06\left(\mathrm{~m}, 60 \mathrm{H}, \mathrm{CH}\left(\mathrm{CH}_{3}\right) \mathrm{C}\left(\mathrm{CH}_{3}\right)_{3}\right), 1.42(\mathrm{~s}, 9 \mathrm{H}, \mathrm{N} t \mathrm{Bu})$, $1.52\left(\mathrm{~s}, 9 \mathrm{H}, \mathrm{CO}_{2} t \mathrm{Bu}\right), 2.09\left(\mathrm{~s}, 3 \mathrm{H}, \mathrm{COCH}_{3}\right) 3.68-4.26\left(\mathrm{~m}, 12 \mathrm{H}, \mathrm{NCH}_{2} \mathrm{CO}\right), 4.62-4.79(\mathrm{~m}, 5 \mathrm{H}, \mathrm{H}$ methyne cis rotamer).

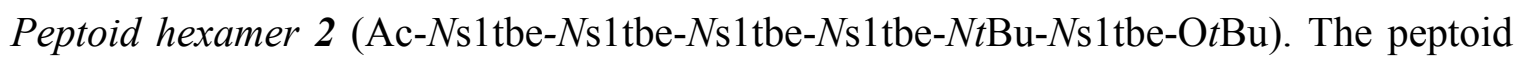
2 was synthesized in 12 steps from tert-butyl bromoacetate $(390 \mathrm{mg}, 2.0 \mathrm{mmol})$ according to procedures $\mathrm{A}$ and $\mathrm{B}$ for the submonomer elongation steps and procedure $\mathrm{C}$ for the final $\mathrm{N}$ terminal acetylation. Peptoid $\mathbf{2}$ was isolated as a white solid after purification by flash column chromatography on silica gel. (350 mg, $0.374 \mathrm{mmol}) ; \mathrm{R}_{f}=0.64$ (100\% EtOAc). m.p. 168.5-169.5 ${ }^{\circ} \mathrm{C}$ HRMS (TOF MS ES+) $m / z$ calcd for $\mathrm{C}_{52} \mathrm{H}_{99} \mathrm{~N}_{6} \mathrm{O}_{8}[\mathrm{M}+\mathrm{H}]^{+}$: 935.7518; found: 935.7524 . Analytical HPLC purity $95 \%$.

${ }^{1} \mathrm{H}$ NMR (400 MHz, $\left.\mathrm{CDCl}_{3}\right) \delta(\mathrm{ppm}): 0.81-1.35\left(\mathrm{~m}, 60 \mathrm{H}, \mathrm{CH}\left(\mathrm{CH}_{3}\right) \mathrm{C}\left(\mathrm{CH}_{3}\right)_{3}\right), 1.41(\mathrm{~s}, 9 \mathrm{H}, \mathrm{N} t \mathrm{Bu})$, $1.45\left(\mathrm{~s}, 3 \mathrm{H}, \mathrm{CO}_{2} t \mathrm{Bu}\right), 1.50\left(\mathrm{~s}, 6 \mathrm{H}, \mathrm{CO}_{2} t \mathrm{Bu}\right), 2.10,\left(\mathrm{~s}, 3 \mathrm{H}, \mathrm{COCH}_{3}\right), 3.61-4.44(\mathrm{~m}, 12.37 \mathrm{H}$, $\mathrm{NCH}_{2} \mathrm{CO}$ and $\mathrm{H}$ methyne trans rotamer), 4.64-4.80 (m, 4.63H, H methyne cis rotamer). 


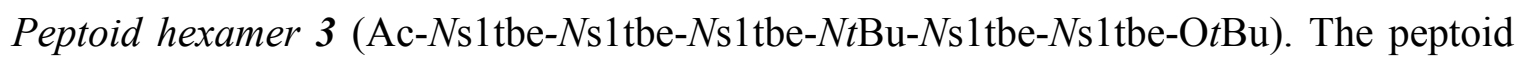
3 was synthesized in 12 steps from tert-butyl bromoacetate $(150 \mathrm{mg}, 0.77 \mathrm{mmol})$ according to procedures $\mathrm{A}$ and $\mathrm{B}$ for the submonomer elongation steps and procedure $\mathrm{C}$ for the final $\mathrm{N}$ terminal acetylation. Peptoid $\mathbf{3}$ was isolated as a white solid after purification by flash column chromatography on silica gel. (72 mg, 0.077mmol); $\mathrm{R}_{f}=0.74$ (100\% EtOAc). m.p. 178.5- 179.5 ${ }^{\circ} \mathrm{C}$ HRMS (TOF MS ES+) $m / z$ calcd for $\mathrm{C}_{52} \mathrm{H}_{99} \mathrm{~N}_{6} \mathrm{O}_{8}[\mathrm{M}+\mathrm{H}]^{+}$: 935.7518; found: 935.7516 . Analytical HPLC purity $97 \%$.

${ }^{1} \mathrm{H}$ NMR (400 MHz, $\left.\mathrm{CDCl}_{3}\right) \delta(\mathrm{ppm}):$ 0.73-1.30 (m, 60H, $\left.\mathrm{CH}\left(\mathrm{CH}_{3}\right) \mathrm{C}\left(\mathrm{CH}_{3}\right) 3\right), 1.38(\mathrm{~s}, 9 \mathrm{H}, \mathrm{N} t \mathrm{Bu})$, $1.42\left(\mathrm{~s}, 3 \mathrm{H}, \mathrm{CO}_{2} \mathrm{Bu}\right), 1.52\left(\mathrm{~s}, 6 \mathrm{H}, \mathrm{CO}_{2} t \mathrm{Bu}\right), 2.05-2.15\left(\mathrm{~m}, 3 \mathrm{H}, \mathrm{COCH}_{3}\right), 3.46-4.26(\mathrm{~m}, 12.56 \mathrm{H}$, $\mathrm{NCH}_{2} \mathrm{CO}$ and $\mathrm{H}$ methyne trans rotamer), $4.61-4.81$ (m, 4.44H, H methyne cis rotamer).

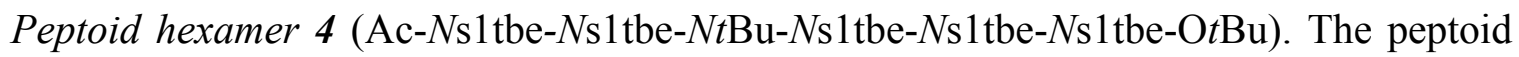
4 was synthesized in 12 steps from tert-butyl bromoacetate $(164 \mathrm{mg}, 0.84 \mathrm{mmol})$ according to procedures $\mathrm{A}$ and $\mathrm{B}$ for the submonomer elongation steps and procedure $\mathrm{C}$ for the final $\mathrm{N}$ terminal acetylation. Peptoid $\mathbf{4}$ was isolated as white solid after purification by flash column chromatography on silica gel. (44 mg, 0.047mmol); $\mathrm{R}_{f}=0.60$ (100\% EtOAc). m.p. 140.5-141.5 ${ }^{\circ} \mathrm{C}$; HRMS (TOF MS ES+) $m / z$ calcd for $\mathrm{C}_{52} \mathrm{H}_{99} \mathrm{~N}_{6} \mathrm{O}_{8}[\mathrm{M}+\mathrm{H}]^{+}$: 935.7518; found: 935.7495 . Analytical HPLC purity $96 \%$.

${ }^{1} \mathrm{H}$ NMR (400 MHz, $\left.\mathrm{CDCl}_{3}\right) \delta(\mathrm{ppm}): 0.81-1.10\left(\mathrm{~m}, 60 \mathrm{H}, \mathrm{CH}\left(\mathrm{CH}_{3}\right) \mathrm{C}\left(\mathrm{CH}_{3}\right)_{3}\right), 1.41(\mathrm{~s}, 9 \mathrm{H}, \mathrm{N} t \mathrm{Bu})$, $1.46\left(\mathrm{~s}, 2.2 \mathrm{H}, \mathrm{CO}_{2} t \mathrm{Bu}\right) 1.51\left(\mathrm{~s}, 6.8 \mathrm{H}, \mathrm{CO}_{2} t \mathrm{Bu}\right), 2.02\left(\mathrm{~s}, 2.34 \mathrm{H}, \mathrm{COCH}_{3}\right), 2.05,(\mathrm{~s}, 0.25 \mathrm{H}$, $\left.\mathrm{COCH}_{3}\right) 2.08\left(\mathrm{~s}, 0.41 \mathrm{H}, \mathrm{COCH}_{3}\right), 3.61-4.44\left(\mathrm{~m}, 12.54 \mathrm{H}, \mathrm{NCH}_{2} \mathrm{CO}\right.$ and $\mathrm{H}$ methyne trans rotamer), 4.64-4.80 (m, 4.46H, H methyne cis rotamer).

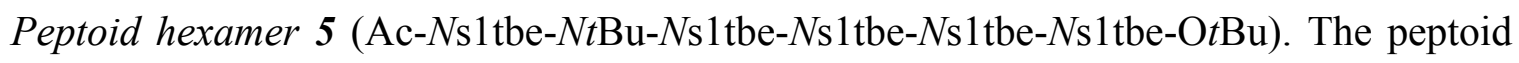
5 was synthesized in 12 steps from tert-butyl bromoacetate $(134 \mathrm{mg}, 0.68 \mathrm{mmol})$ according to procedures $\mathrm{A}$ and $\mathrm{B}$ for the submonomer elongation steps and procedure $\mathrm{C}$ for the final $\mathrm{N}$ terminal acetylation. Peptoid $\mathbf{5}$ was isolated as a white solid after purification by flash column chromatography on silica gel. (142 mg, $0.15 \mathrm{mmol}$ ); $\mathrm{R}_{f}=0.70$ (EtOAc). m.p. 160.1-160.5 ${ }^{\circ} \mathrm{C}$ HRMS (TOF MS ES+) m/z calcd for $\mathrm{C}_{52} \mathrm{H}_{98} \mathrm{~N}_{6} \mathrm{O}{ }_{8} \mathrm{Na}[\mathrm{M}+\mathrm{Na}]^{+}$: 957.7339; found: 957.7305 . Analytical HPLC purity $98 \%$.

${ }^{1} \mathrm{H}$ NMR (400 MHz, $\left.\mathrm{CDCl}_{3}\right) \delta(\mathrm{ppm}):$ 0.81-1.08 (m, 59.2H, $\left.\mathrm{CH}\left(\mathrm{CH}_{3}\right) \mathrm{C}\left(\mathrm{CH}_{3}\right)_{3}\right), 1.33(\mathrm{~d}, J=7.3$ $\mathrm{Hz}, 0.8 \mathrm{H}, \mathrm{CH}\left(\mathrm{CH}_{3}\right) \mathrm{C}\left(\mathrm{CH}_{3}\right)_{3}$ trans rotamer), $1.39\left(\mathrm{~s}, 2.5 \mathrm{H}, \mathrm{CO}_{2} t \mathrm{Bu}\right), 1.42(\mathrm{~s}, 9 \mathrm{H}, \mathrm{N} t \mathrm{Bu}), 1.51$ (s, 6.5H, $\left.\mathrm{CO}_{2} t \mathrm{Bu}\right), 1.98-2.22\left(3 \mathrm{H}, \mathrm{COCH}_{3}\right), 3.5-4.37\left(\mathrm{~m}, 12.54 \mathrm{H}, \mathrm{NCH}_{2} \mathrm{CO}\right.$ and $\mathrm{H}$ methyne trans rotamer), 4.50-4.90 (m, 4.46H, $\mathrm{H}$ methyne cis rotamer). 


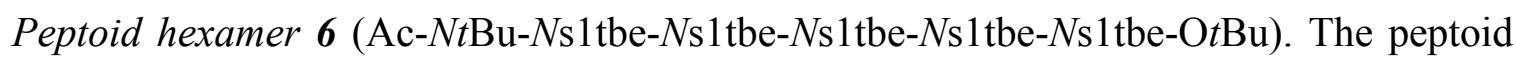
6 was synthesized in 12 steps from tert-butyl bromoacetate $(97 \mathrm{mg}, 0.50 \mathrm{mmol})$ according to procedures $\mathrm{A}$ and $\mathrm{B}$ for the submonomer elongation steps and procedure $\mathrm{C}$ for the final $\mathrm{N}$ terminal acetylation. Peptoid 6 was isolated as a solid after purification by flash column chromatography on silica gel. (149 mg, $0.16 \mathrm{mmol}$ ); $\mathrm{R}_{f}=0.70$ (EtOAc). m.p. 148.2-148.6 ${ }^{\circ} \mathrm{C}$ HRMS (TOF MS ES+) $m / z$ calcd for $\mathrm{C}_{52} \mathrm{H}_{99} \mathrm{~N}_{6} \mathrm{O}_{8}[\mathrm{M}+\mathrm{H}]^{+}$: 935.7518; found: 935.7491 . Analytical HPLC purity $98 \%$.

${ }^{1} \mathrm{H} \quad \mathrm{NMR} \quad\left(400 \mathrm{MHz}, \mathrm{CDCl}_{3}\right) \quad \delta \quad(\mathrm{ppm}): 0.82-1.08 \quad\left(\mathrm{~m}, \quad 59.2 \mathrm{H}, \quad \mathrm{CH}\left(\mathrm{CH}_{3}\right) \mathrm{C}\left(\mathrm{CH}_{3}\right)_{3}\right.$ and $\mathrm{CH}\left(\mathrm{CH}_{3}\right) \mathrm{C}\left(\mathrm{CH}_{3}\right)_{3}$ cis rotamer $), 1.33\left(\mathrm{~d}, \mathrm{~J}=6.8 \mathrm{~Hz}, 0.8 \mathrm{H}, \mathrm{CH}\left(\mathrm{CH}_{3}\right) \mathrm{C}\left(\mathrm{CH}_{3}\right)_{3}\right.$ trans rotamer $), 1.40-$ $1.54\left(\mathrm{~m}, 18 \mathrm{H}, \mathrm{Nt} \mathrm{Bu}\right.$ and $\left.\mathrm{CO}_{2} t \mathrm{Bu}\right), 1.98-2.21\left(\mathrm{~m}, 3 \mathrm{H}, \mathrm{COCH}_{3}\right), 3.46-4.28\left(\mathrm{~m}, 12.50 \mathrm{H}, \mathrm{NCH}_{2} \mathrm{CO}\right.$ and $\mathrm{H}$ methyne trans rotamer), 4.62-4.79 (m, 4.50H, $\mathrm{H}$ methyne cis rotamer).

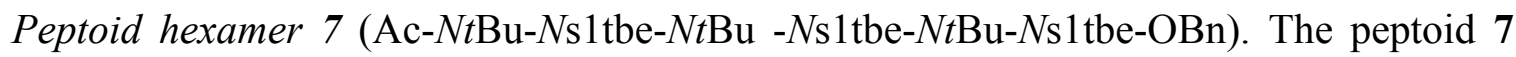
was synthesized in 12 steps from benzyl bromoacetate $(452 \mathrm{mg}, 1.97 \mathrm{mmol}$ ) according to procedures $\mathrm{A}$ and $\mathrm{B}$ for the submonomer elongation steps and procedure $\mathrm{C}$ for the final $\mathrm{N}$ terminal acetylation. Peptoid 7 was isolated as a white solid after purification by flash column chromatography on silica gel. (110 mg, $0.12 \mathrm{mmol}$ ); $\mathrm{R}_{f}=0.85$ (EtOAc). m.p. 134.7-135.2 ${ }^{\circ} \mathrm{C}$. HRMS (TOF MS ES+) $m / z$ calcd for $\mathrm{C}_{51} \mathrm{H}_{89} \mathrm{~N}_{6} \mathrm{O}_{8}[\mathrm{M}+\mathrm{H}]^{+}: 913.6736$; found: 913.6724 Analytical HPLC purity $98 \%$.

${ }^{1} \mathrm{H} \quad \mathrm{NMR} \quad\left(400 \quad \mathrm{MHz}, \quad \mathrm{CDCl}_{3}\right) \quad \delta \quad(\mathrm{ppm}): \quad 0.73-1.18 \quad\left(\mathrm{~m}, \quad 33 \mathrm{H}, \quad \mathrm{CH}\left(\mathrm{CH}_{3}\right) \mathrm{C}\left(\mathrm{CH}_{3}\right)_{3}\right.$ and $\mathrm{CH}\left(\mathrm{CH}_{3}\right) \mathrm{C}\left(\mathrm{CH}_{3}\right)_{3}$ cis rotamer), 1.22-1.32 (m, 3H, $\mathrm{CH}\left(\mathrm{CH}_{3}\right) \mathrm{C}\left(\mathrm{CH}_{3}\right)_{3}$ trans rotamer), 1.33-1.53 (m, 27H, NtBu), 1.95-2.16 (m, 3H, $\left.\mathrm{COCH}_{3}\right), 3.25-4.56\left(\mathrm{~m}, 13.0 \mathrm{H}, \mathrm{NCH}_{2} \mathrm{CO}\right.$ and $\mathrm{H}$ methyne trans rotamer), $4.74\left(\mathrm{~s}, 2 \mathrm{H}, \mathrm{OCH}_{2} \mathrm{Ph}\right), 5.01-5.31$ (m, 2.0H, $\mathrm{H}$ methyne cis rotamer), 7.28-7.45 (m, 5H, $\mathrm{Ph}$ ).

Peptoid hexamer 8 (Ac-NtBu-Ns1tbe-NtBu -Ns1tbe-NtBu-Ns1tbe-OH). To a solution of peptoid $7(50 \mathrm{mg}, 0.055 \mathrm{mmol})$ in $\mathrm{MeOH}(5 \mathrm{~mL})$, carefully purged with argon was added a catalytic amount of $10 \% \mathrm{Pd} / \mathrm{C}(5 \mathrm{mg})$. The suspension was then stirred for $30 \mathrm{~min}$ under an atmosphere of hydrogen. The mixture was filtered through a plug of celite which was rinsed with $\mathrm{MeOH}$. The solvent was removed in vacuo to yield peptoid $\mathbf{8}$ as a white solid after purification by flash column chromatography on silica gel. (45.5 mg, $0.054 \mathrm{mmol}$ ); $\mathrm{R}_{\mathrm{f}}=0.50$ (EtOAc). m.p. 213.9-214.4 ${ }^{\circ} \mathrm{C}$. HRMS (TOF MS ES+) $m / z$ calcd for $\mathrm{C}_{44} \mathrm{H}_{83} \mathrm{~N}_{6} \mathrm{O}_{8}[\mathrm{M}+\mathrm{H}]^{+}:$823.6266; found: 823.6267. Analytical HPLC purity $96 \%$.

${ }^{1} \mathrm{H} \quad \mathrm{NMR} \quad\left(400 \mathrm{MHz}, \mathrm{CDCl}_{3}\right) \quad \delta \quad(\mathrm{ppm}): \quad 0.78-1.13 \quad\left(\mathrm{~m}, \quad 34.1 \mathrm{H}, \quad \mathrm{CH}\left(\mathrm{CH}_{3}\right) \mathrm{C}\left(\mathrm{CH}_{3}\right)_{3}\right.$ and $\mathrm{CH}\left(\mathrm{CH}_{3}\right) \mathrm{C}\left(\mathrm{CH}_{3}\right)_{3}$ cis rotamer $), 1.23-1.51\left(\mathrm{~m}, 28.9 \mathrm{H}, \mathrm{Nt} \mathrm{Bu}\right.$ and $\mathrm{CH}\left(\mathrm{CH}_{3}\right) \mathrm{C}\left(\mathrm{CH}_{3}\right)_{3}$ trans rotamer $)$, 
2.01-2.34 (m, 3H, $\left.\mathrm{COCH}_{3}\right), 3.29-4.51\left(\mathrm{~m}, 12.63 \mathrm{H}, \mathrm{NCH}_{2} \mathrm{CO}\right.$ and $\mathrm{H}$ methyne trans rotamer), 4.58-4.80 (m, 2.37H, $\mathrm{H}$ methyne cis rotamer), $11.64\left(\mathrm{bs}, 1 \mathrm{H}, \mathrm{CO}_{2} \mathrm{H}\right)$.

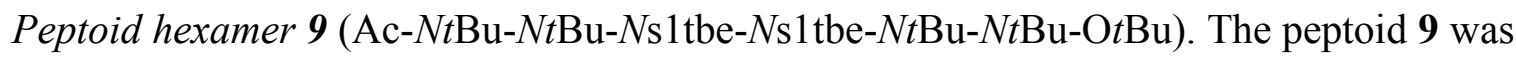
synthesized in 12 steps from tert-butyl bromoacetate (264 $\mathrm{mg}, 1.35 \mathrm{mmol}$ ) according to procedures $\mathrm{A}$ and $\mathrm{B}$ for the submonomer elongation steps and procedure $\mathrm{C}$ for the final $\mathrm{N}$ terminal acetylation. Peptoid 9 was isolated as a white solid after purification by flash column chromatography on silica gel. (248 mg, $0.29 \mathrm{mmol}) ; \mathrm{R}_{f}=0.84$ (EtOAc). m.p. $144.3-144.7^{\circ} \mathrm{C}$. HRMS (TOF MS ES+) m/z calcd for $\mathrm{C}_{46} \mathrm{H}_{87} \mathrm{~N}_{6} \mathrm{O}_{8}[\mathrm{M}+\mathrm{H}]^{+}$: 851.6580; found: 851.6578 . Analytical HPLC purity 99\%.

${ }^{1} \mathrm{H}$ NMR (400 MHz, $\left.\mathrm{CDCl}_{3}\right) \delta$ (ppm): 0.84-0.94 (m, 18H, $\left.\mathrm{CH}\left(\mathrm{CH}_{3}\right) \mathrm{C}\left(\mathrm{CH}_{3}\right)_{3}\right), 0.98-1.07$ (m, 6H $\mathrm{CH}\left(\mathrm{CH}_{3}\right) \mathrm{C}\left(\mathrm{CH}_{3}\right)_{3}$ cis rotamer), 1.35-1.46 (m, 36H, NtBu), $1.50\left(\mathrm{~s}, 9 \mathrm{H}, \mathrm{CO}_{2} t \mathrm{Bu}\right), 1.88-2.04(\mathrm{~m}$, $\left.3 \mathrm{H}, \mathrm{COCH}_{3}\right), 3.37-4.40\left(\mathrm{~m}, 12 \mathrm{H}, \mathrm{NCH}_{2} \mathrm{CO}\right), 4.57-4.79$ (m, 2H, H methyne cis rotamer).

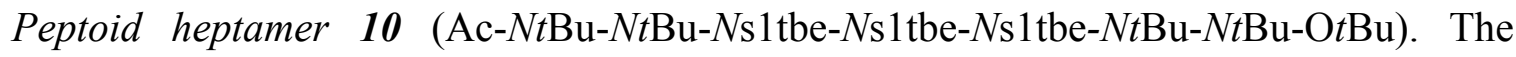
peptoid 10 was synthesized in 14 steps from tert-butyl bromoacetate $(264 \mathrm{mg}, 1.35 \mathrm{mmol})$ according to procedures $\mathrm{A}$ and $\mathrm{B}$ for the submonomer elongation steps and procedure $\mathrm{C}$ for the final N-terminal acetylation. Peptoid 1 was isolated as a white foam after purification by flash column chromatography on silica gel. (178 mg, $0.18 \mathrm{mmol}$ ); $\mathrm{R}_{f}=0.80$ (EtOAc). HRMS (TOF MS ES+) $m / z$ calculated for $\mathrm{C}_{54} \mathrm{H}_{101} \mathrm{~N}_{7} \mathrm{O}_{9} \mathrm{Na}[\mathrm{M}+\mathrm{Na}]^{+}:$1014.7553; found: 1014.7476. Analytical HPLC purity $97 \%$.

${ }^{1} \mathrm{H} \quad \mathrm{NMR} \quad\left(400 \quad \mathrm{MHz}, \mathrm{CDCl}_{3}\right) \quad \delta \quad(\mathrm{ppm}): \quad 0.84-1.08 \quad\left(\mathrm{~m}, \quad 36 \mathrm{H}, \quad \mathrm{CH}\left(\mathrm{CH}_{3}\right) \mathrm{C}\left(\mathrm{CH}_{3}\right)_{3}\right.$ and $\mathrm{CH}\left(\mathrm{CH}_{3}\right) \mathrm{C}\left(\mathrm{CH}_{3}\right)_{3}$ cis rotamer), 1.36-1.47 (m, 36H, NtBu), 1.51 (s, 9H, $\left.\mathrm{CO}_{2} t \mathrm{Bu}\right), 1.90-2.10$ (m, $\left.3 \mathrm{H}, \mathrm{COCH}_{3}\right), 3.70-4.37$ (m, 19H, $\left.\mathrm{NCH}_{2} \mathrm{CO}\right), 4.61-4.86$ (m, 3H, H methyne cis rotamer).

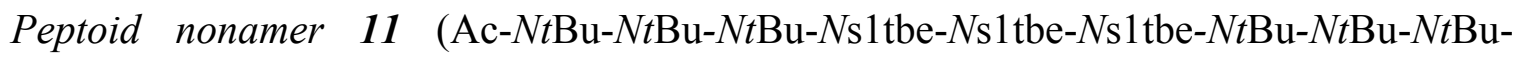
$\mathrm{O} t \mathrm{Bu}$ ). The peptoid 11 was synthesized in 17 steps from tert-butyl bromoacetate $(264 \mathrm{mg}, 1.35$ mmol) according to procedures $\mathrm{A}$ and $\mathrm{B}$ for the submonomer elongation steps and procedure $\mathrm{C}$ for the final N-terminal acetylation. Peptoid 11 was isolated as a white solid after purification by flash column chromatography on silica gel. (252 mg, $0.21 \mathrm{mmol}$ ); $\mathrm{R}_{f}=0.87$ (EtOAc). m.p. 165.9-166. $7^{\circ} \mathrm{C}$ HRMS (TOF MS ES+) $m / z$ calcd for $\mathrm{C}_{66} \mathrm{H}_{124} \mathrm{~N}_{9} \mathrm{O}_{11}[\mathrm{M}+\mathrm{H}]^{+}: 1218.9342$; found: 1218.9441. Analytical HPLC purity 95\%.

${ }^{1} \mathrm{H} \quad \mathrm{NMR} \quad\left(400 \quad \mathrm{MHz}, \quad \mathrm{CDCl}_{3}\right) \quad \delta \quad(\mathrm{ppm}): \quad 0.81-1.08 \quad\left(\mathrm{~m}, \quad 36 \mathrm{H}, \quad \mathrm{CH}\left(\mathrm{CH}_{3}\right) \mathrm{C}\left(\mathrm{CH}_{3}\right)_{3}\right.$ and $\mathrm{CH}\left(\mathrm{CH}_{3}\right) \mathrm{C}\left(\mathrm{CH}_{3}\right)_{3}$ cis rotamer), 1.32-1.49 (m, 54H, NtBu), $1.52\left(\mathrm{~s}, 9 \mathrm{H}, \mathrm{CO}_{2} t \mathrm{Bu}\right), 1.89-2.10(\mathrm{~m}$, $\left.3 \mathrm{H}, \mathrm{COCH}_{3}\right), 3.42-4.39$ (m, $\left.14 \mathrm{H}, \mathrm{NCH}_{2} \mathrm{CO}\right), 4.62-4.82$ (m, 3H, H methyne cis rotamer). 


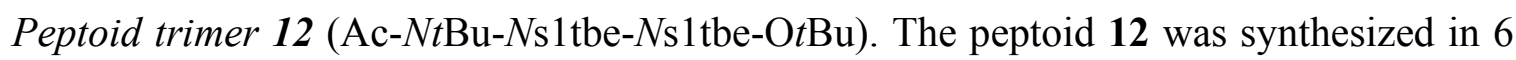
steps from tert-butyl bromoacetate $(74 \mathrm{mg}, 0.38 \mathrm{mmol})$ according to procedures $\mathrm{A}$ and $\mathrm{B}$ for the submonomer elongation steps and procedure $\mathrm{C}$ for the final N-terminal acetylation. Peptoid 12 was isolated as a white solid after purification by flash column chromatography on silica gel. (94 mg, $0.18 \mathrm{mmol}$ ); $\mathrm{R}_{f}=0.48$ (EtOAc/cyclohexane 60:40). m.p. 200-201 ${ }^{\circ} \mathrm{C}$ HRMS (TOF MS ES + ) $m / z$ calcd for $\mathrm{C}_{28} \mathrm{H}_{54} \mathrm{~N}_{3} \mathrm{O}_{5}[\mathrm{M}+\mathrm{H}]^{+}:$512.4058; found: 512.4059. Analytical HPLC purity $99 \%$.

${ }^{1} \mathrm{H} \quad \mathrm{NMR} \quad\left(400 \mathrm{MHz}, \mathrm{CDCl}_{3}\right) \quad \delta \quad(\mathrm{ppm}): \quad 0.84-1.10 \quad\left(\mathrm{~m}, \quad 21.9 \mathrm{H}, \mathrm{CH}\left(\mathrm{CH}_{3}\right) \mathrm{C}\left(\mathrm{CH}_{3}\right)_{3}\right.$ and $\mathrm{CH}\left(\mathrm{CH}_{3}\right) \mathrm{C}\left(\mathrm{CH}_{3}\right)_{3}$ cis rotamer), 1.21-1.28 (m, 2.1H, $\mathrm{CH}\left(\mathrm{CH}_{3}\right) \mathrm{C}\left(\mathrm{CH}_{3}\right)_{3}$ trans rotamer), 1.39-1.52 (m, $18 \mathrm{H}, N t \mathrm{Bu}$ and $\left.\mathrm{CO}_{2} t \mathrm{Bu}\right), 1.93-2.06\left(\mathrm{~m}, 3 \mathrm{H}, \mathrm{COCH}_{3}\right), 3.48-3.61(\mathrm{~m}, 0.70 \mathrm{H}, \mathrm{H}$ methyne trans rotamer), 3.70-4.36 (m, $\left.6 \mathrm{H}, \mathrm{NCH}_{2} \mathrm{CO}\right), 4.64-4.82$ (m, 1.30H, $\mathrm{H}$ methyne cis rotamer).

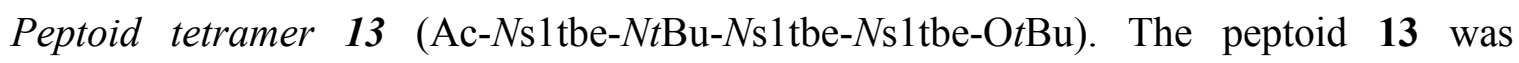
synthesized in 8 steps from tert-butyl bromoacetate $(70 \mathrm{mg}, 0.36 \mathrm{mmol}$ ) according to procedures $\mathrm{A}$ and $\mathrm{B}$ for the submonomer elongation steps and procedure $\mathrm{C}$ for the final $\mathrm{N}$-terminal acetylation. Peptoid $\mathbf{1 3}$ was isolated as a white solid after purification by flash column chromatography on silica gel. (56 mg, $0.08 \mathrm{mmol}$ ); $\mathrm{R}_{f}=0.53$ (EtOAc/cyclohexane 60:40). m.p. 118.3-118.9 ${ }^{\circ} \mathrm{C}$ HRMS (TOF MS ES+) $m / z$ calcd for $\mathrm{C}_{36} \mathrm{H}_{69} \mathrm{~N}_{4} \mathrm{O}_{6}[\mathrm{M}+\mathrm{H}]^{+}: 653.5211$; found: 653.5214. Analytical HPLC purity 99\%.

${ }^{1} \mathrm{H} \quad \mathrm{NMR}\left(400 \mathrm{MHz}, \mathrm{CDCl}_{3}\right) \quad \delta$ (ppm): $0.84-1.10 \quad\left(\mathrm{~m}, \quad 33.06 \mathrm{H}, \mathrm{CH}\left(\mathrm{CH}_{3}\right) \mathrm{C}\left(\mathrm{CH}_{3}\right)_{3}\right.$ and $\mathrm{CH}\left(\mathrm{CH}_{3}\right) \mathrm{C}\left(\mathrm{CH}_{3}\right)_{3}$ cis rotamer), 1.22-1.32 (m, 2.94H, $\mathrm{CH}\left(\mathrm{CH}_{3}\right) \mathrm{C}\left(\mathrm{CH}_{3}\right)_{3}$ trans rotamer), 1.35-1.55 $\left(\mathrm{m}, 18 \mathrm{H}, N t \mathrm{Bu}\right.$ and $\left.\mathrm{CO}_{2} \mathrm{Bu}\right), 1.89-2.06\left(\mathrm{~m}, 2.02 \mathrm{H}, \mathrm{COCH}_{3}\right), 2.11-2.18\left(\mathrm{~m}, 0.98 \mathrm{H}, \mathrm{COCH}_{3}\right)$, 3.34-4.41 (m, 8.98H, $\mathrm{NCH}_{2} \mathrm{CO}$ and $\mathrm{H}$ methyne trans rotamer), 4.61-4.81 (m, 2.02H, $\mathrm{H}$ methyne cis rotamer).

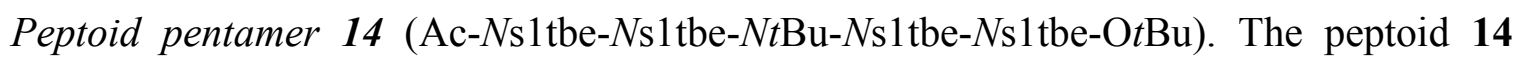
was synthesized in 10 steps from tert-butyl bromoacetate $(96 \mathrm{mg}, 0.49 \mathrm{mmol})$ according to procedures $\mathrm{A}$ and $\mathrm{B}$ for the submonomer elongation steps and procedure $\mathrm{C}$ for the final $\mathrm{N}$ terminal acetylation. Peptoid $\mathbf{1 4}$ was isolated as a white solid after purification by flash column chromatography on silica gel. (67mg, $0.08 \mathrm{mmol}$ ); $\mathrm{R}_{f}=0.60$ (EtOAc). m.p. 224-225 ${ }^{\circ} \mathrm{C}$. HRMS (TOF MS ES + ) $m / z$ calcd for $\mathrm{C}_{44} \mathrm{H}_{84} \mathrm{~N}_{5} \mathrm{O}_{7}[\mathrm{M}+\mathrm{H}]^{+}:$794.6365; found: 794.6371. Analytical HPLC purity $98 \%$.

${ }^{1} \mathrm{H} \quad \mathrm{NMR} \quad\left(400 \mathrm{MHz}, \mathrm{CDCl}_{3}\right) \quad \delta$ (ppm): $0.78-1.12 \quad\left(\mathrm{~m}, \quad 45.36 \mathrm{H}, \mathrm{CH}\left(\mathrm{CH}_{3}\right) \mathrm{C}\left(\mathrm{CH}_{3}\right)_{3}\right.$ and $\mathrm{CH}\left(\mathrm{CH}_{3}\right) \mathrm{C}\left(\mathrm{CH}_{3}\right)_{3}$ cis rotamer), 1.22-1.60 (m, 20.64H, $N t \mathrm{Bu}$ and $\mathrm{CO}_{2} t \mathrm{Bu}$ and $\mathrm{CH}\left(\mathrm{CH}_{3}\right) \mathrm{C}\left(\mathrm{CH}_{3}\right)_{3}$ trans rotamer), 1.92-2.08 (m, 2.31H, $\left.\mathrm{COCH}_{3}\right), 2.12-2.24\left(\mathrm{~m}, 0.69 \mathrm{H}, \mathrm{COCH}_{3}\right), 3.34-4.46(\mathrm{~m}$, $10.88 \mathrm{H}, \mathrm{NCH}_{2} \mathrm{CO}$ and $\mathrm{H}$ methyne trans rotamer), 4.60-4.86 (m, 3.12H, H methyne cis rotamer). 


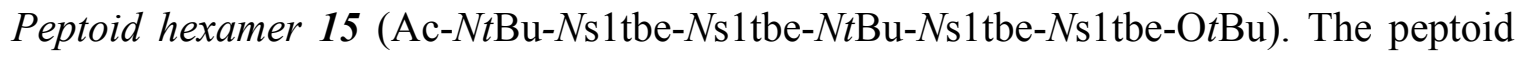
15 was synthesized in 12 steps from tert-butyl bromoacetate $(97 \mathrm{mg}, 0.49 \mathrm{mmol})$ according to procedures $\mathrm{A}$ and $\mathrm{B}$ for the submonomer elongation steps and procedure $\mathrm{C}$ for the final $\mathrm{N}$ terminal acetylation. Peptoid $\mathbf{1 5}$ was isolated as a white solid after purification by flash column chromatography on silica gel. (42 mg, $0.046 \mathrm{mmol}) ; \mathrm{R}_{\mathrm{f}}=0.66$ (100\% EtOAc). m.p. 135.8-136.5 ${ }^{\circ} \mathrm{C}$. HRMS (TOF MS ES+) $m / z$ calcd for for $\mathrm{C}_{50} \mathrm{H}_{95} \mathrm{~N}_{6} \mathrm{O} 8$ [M+H $]^{+}: 907.7205$; found: 907.7216 . Analytical HPLC purity $98 \%$.

${ }^{1} \mathrm{H}$ NMR $\left(400 \mathrm{MHz}, \mathrm{CDCl}_{3}\right) \delta(\mathrm{ppm}):$ 0.79-1.26 (m, 48H, $\left.\left.\mathrm{CH}\left(\mathrm{CH}_{3}\right) \mathrm{C}\left(\mathrm{CH}_{3}\right)\right)_{3}\right), 1.27-1.55(\mathrm{~m}, 27 \mathrm{H}$, $N t \mathrm{Bu}$ and $\left.\mathrm{CO}_{2} t \mathrm{Bu}\right), 1.93-2.14\left(\mathrm{~m}, 3 \mathrm{H}, \mathrm{COCH}_{3}\right), 3.45-4.30\left(\mathrm{~m}, 12.69 \mathrm{H}, \mathrm{NCH}_{2} \mathrm{CO}\right.$ and $\mathrm{H}$ methyne trans rotamer), 4.62-4.77 (m, 3.31H, $\mathrm{H}$ methyne cis rotamer).

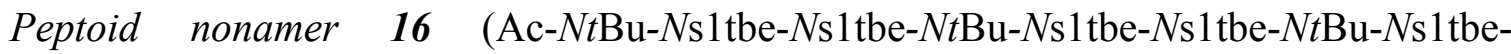
$N \mathrm{~s} 1$ tbe-O $t \mathrm{Bu}$ ). The peptoid 16 was synthesized in 18 steps from tert-butyl bromoacetate (292 $\mathrm{mg}, 1.50 \mathrm{mmol}$ ) according to procedures $\mathrm{A}$ and $\mathrm{B}$ for the submonomer elongation steps and procedure $\mathrm{C}$ for the final $\mathrm{N}$-terminal acetylation. Peptoid $\mathbf{1 6}$ was isolated as a white solid after purification by flash column chromatography on silica gel. (22 $\mathrm{mg}, 0.017 \mathrm{mmol}) ; \mathrm{Rf}=0.55$ (100\% EtOAc). m.p. 153.4-154.0 ${ }^{\circ} \mathrm{C}$. HRMS (TOF MS ES+) $m / z$ calcd for $\mathrm{C}_{72} \mathrm{H}_{136} \mathrm{~N}_{9} \mathrm{O}_{11}$ $[\mathrm{M}+\mathrm{H}]^{+}:$1303.0353; found: 1303.0353. Analytical HPLC purity 99\%.

${ }^{1} \mathrm{H}$ NMR (400 MHz, $\left.\mathrm{CDCl}_{3}\right) \delta(\mathrm{ppm}): 0.76-1.16\left(\mathrm{~m}, 72 \mathrm{H}, \mathrm{CH}\left(\mathrm{CH}_{3}\right) \mathrm{C}\left(\mathrm{CH}_{3}\right)_{3}\right), 1.31-1.51(\mathrm{~m}, 36 \mathrm{H}$, $N t \mathrm{Bu}$ and $\left.\mathrm{CO}_{2} t \mathrm{Bu}\right), 1.91-2.03\left(\mathrm{~m}, 3 \mathrm{H}, \mathrm{COCH}_{3}\right), 3.39-4.37\left(\mathrm{~m}, 19.2 \mathrm{H}, \mathrm{NCH}_{2} \mathrm{CO}\right.$ and $\mathrm{H}$ methyne trans rotamer), 4.60- 4.81(m, 4.8H, $\mathrm{H}$ methyne cis rotamer).

\section{ASSOCIATED CONTENT}

General synthetic scheme, HPLC traces, ${ }^{1} \mathrm{H}$ NMR and HSQCAD spectra, CD of a number of different peptoid oligomers, crystal structure report for peptoids $\mathbf{1 2}$ and $\mathbf{1 4 .}$

X-ray crystallographic data for compounds 12 (CCDC 1960900) (CIF) and 14 (CCDC 1960948) (CIF).

\section{AUTHOR INFORMATION}

ORCID

Claude Taillefumier: 0000-0003-3126-495X

\section{ACKNOWLEDGEMENTS}

We thank Aurélie Job for HPLC measurements and Martin Leremboure (UCA Partner) for LCMS. M.R. was supported by a grant from the Ministry for Higher Education and Scientific 
Research of Tunisia. We acknowledge use of the UMS2008-IBSLor Biophysics and Structural Biology core facility at Université de Lorraine for CD measurements.

${ }^{1}$ Culf, A. S.; Ouellette, R. J. Solid-Phase Synthesis of N-Substituted Glycine Oligomers (alpha-Peptoids) and Derivatives. Molecules 2010, 15, 5282-5335.

${ }^{2}$ Knight, A. S.; Zhou, E. Y.; Francis, M. B.; Zuckermann, R. N. Sequence Programmable Peptoid Polymers for Diverse Materials Applications. Adv. Mater. 2015, 27, 5665-5691.

${ }^{3}$ Gangloff, N.; Ulbricht, J.; Lorson, T.; Schlaad, H.; Luxenhofer, R. Peptoids and Polypeptoids at the Frontier of Supra- and Macromolecular Engineering. Chem. Rev. 2016, 116, 1753-1802.

${ }^{4}$ Zuckermann, R. N.; Kodadek, T. Peptoids as potential therapeutics. Curr. Opin. Mol. Ther. 2009, 11, $299-307$.

${ }^{5}$ Dohm, M. T.; Kapoor, R.; Barron, A. E. Peptoids: Bio-Inspired Polymers as Potential Pharmaceuticals. Curr. Pharm. Des. 2011, 17, 2732-2747.

${ }^{6}$ Horne, W. S. Peptide and peptoid foldamers in medicinal chemistry. Expert Opin. Drug Dis. 2011, 6, $1247-1262$.

${ }^{7}$ Maayan, G.; Ward, M. D.; Kirshenbaum, K. Metallopeptoids. Chem. Commun., 2009, 56-58.

${ }^{8}$ Maayan, G.; Ward, M. D.; Kirshenbaum, K. Folded biomimetic oligomers for enantioselective catalysis. Proc. Natl. Acad. Sci. USA 2009, 106, 13679-13684.

${ }^{9}$ Zborovsky, L.; Tigger-Zaborov, H.; Maayan, G. Sequence and Structure of Peptoid Oligomers Can Tune the Photoluminescence of an Embedded Ruthenium Dye. Chem. Eur. J. 2019, 25, 9098-9107.

${ }^{10}$ Zuckermann, R. N.; Kerr, J. M.; Kent, S. B. H.; Moos, W. H. Efficient method for the preparation of peptoids [oligo(N-substituted glycines)] by submonomer solid-phase synthesis. J. Am. Chem. Soc. 1992, 114, 10646-10647.

${ }^{11}$ Miller, S. M.; Simon, R. J.; Ng, S.; Zuckermann, R. N.; Kerr, J. M.; Moos, W. H. Proteolytic Studies of Homologous Peptide and N-Substituted Glycine Peptoid Oligomers. Bioorg. Med. Chem. Lett. 1994, 4, $2657-2662$.

${ }^{12}$ Miller, S. M.; Simon, R. J.; Ng, S.; Zuckermann, R. N.; Kerr, J. M.; Moos, W. H. Comparison of the Proteolytic Susceptibilities of Homologous L-Amino-Acid, D-Amino-Acid, and N-Substituted Glycine Peptide and Peptoid Oligomers. Drug Dev. Res. 1995, 35, 20-32.

${ }_{13}$ Armand, P.; Kirshenbaum, K.; Goldsmith, R. A.; Farr-Jones, S.; Barron, A. E.; Truong, K. T. V.; Dill, K. A.; Mierke, D. F.; Cohen, F. E.; Zuckermann, R. N.; Bradley, E. K. NMR determination of the major solution conformation of a peptoid pentamer with chiral side chains. Proc. Natl. Acad. Sci. USA 1998, 95, 4309-4314.

${ }^{14}$ Wu, C. W.; Kirshenbaum, K.; Sanborn, T. J.; Patch, J. A.; Huang, K.; Dill, K. A.; Zuckermann, R. N.; Barron, A. E. Structural and spectroscopic studies of peptoid oligomers with $\alpha$-chiral aliphatic side chains. J. Am. Chem. Soc. 2003, 125, 13525-13530.

${ }^{15}$ Stringer, J. R.; Crapster, J. A.; Guzei, I. A.; Blackwell, H. E. Extraordinarily Robust Polyproline Type I Peptoid Helices Generated via the Incorporation of alpha-Chiral Aromatic N-1-Naphthylethyl Side Chains. J. Am. Chem. Soc. 2011, 133 (39), 15559-15567.

${ }^{16}$ Roy, O.; Dumonteil, G.; Faure, S.; Jouffret, L.; Kriznik, A.; Taillefumier, C. Homogeneous and Robust Polyproline Type I Helices from Peptoids with Nonaromatic $\alpha$-Chiral Side Chains. J. Am. Chem. Soc. 2017, 139, 13533-13540.

${ }^{17}$ Shah, N. H.; Butterfoss, G. L.; Nguyen, K.; Yoo, B.; Bonneau, R.; Rabenstein, D. L.; Kirshenbaum, K. Oligo(Naryl glycines): A New Twist on Structured Peptoids. J. Am. Chem. Soc. 2008, 130, 16622-16632.

${ }^{18}$ Crapster, J. A.; Stringer, J. R.; Guzei, I. A.; Blackwell, H. E. Design and Conformational Analysis of Peptoids Containing N-Hydroxy Amides Reveals a Unique Sheet-Like Secondary Structure. Biopolymers 2011, 96, $604-616$.

19 (a) Shin, S. B.; Yoo, B.; Todaro, L. J.; Kirshenbaum, K. Cyclic Peptoids. J. Am. Chem. Soc. 2007, 129, 32183225. (b) D'Amato, A.; Pierri, G.; Tedesco, C.; Della Sala, G.; Izzo, I.; Costabile, C.; De Riccardis, F. Reverse Turn and Loop Secondary Structures in Stereodefined Cyclic Peptoid Scaffolds. J. Org. Chem. 2019, 84, 10911-10928. (c) Huang, K.; Wu, C. W.; Sanborn, T. J.; Patch, J. A.; Kirshenbaum, K.; Zuckermann, R. N.; Barron, A. E.; Radhakrishnan, I. A Threaded Loop Conformation Adopted by a Family of Peptoid Nonamers. J. Am. Chem. Soc. 2006, 128, 1733-1738.

${ }^{20}$ Gorske, B. C.; Mumford, E. M.; Gerrity, C. G.; Ko, I. A Peptoid Square Helix via Synergistic Control of Backbone Dihedral Angles. J. Am. Chem. Soc. 2017, 139, 8070-8073.

${ }^{21}$ Crapster, J. A.; Guzei, I. A.; Blackwell, H. E. A Peptoid Ribbon Secondary Structure. Angew. Chem. Int. Ed. 2013, 52 (19), 5079-5084.

${ }^{22}$ Gorske, B. C.; Mumford, E. M.; Conry, R. R. Tandem Incorporation of Enantiomeric Residues Engenders Discrete Peptoid Structures. Org. Lett. 2016, 18, 2780-2783.

${ }^{23}$ Sui, Q.; Borchardt, D.; Rabenstein, D. L. Kinetics and Equilibria of Cis/Trans Isomerization of Backbone Amide Bonds in Peptoids. J. Am. Chem. Soc. 2007, 129, 12042-12048. 
${ }^{24}$ Butterfoss, G. L.; Renfrew, P. D.; Kuhlman, B.; Kirshenbaum, K.; Bonneau, R. A Preliminary Survey of the Peptoid Folding Landscape. J. Am. Chem. Soc. 2009, 131, 16798-16807.

${ }^{25}$ Gorske, B. C.; Bastian, B. L.; Geske, G. D.; Blackwell, H. E. Local and tunable n ->pi* interactions regulate amide isomerism in the peptoid backbone. J. Am. Chem. Soc. 2007, 129, 8928-8929.

${ }^{26}$ Gorske, B. C.; Stringer, J. R.; Bastian, B. L.; Fowler, S. A.; Blackwell, H. E. New Strategies for the Design of Folded Peptoids Revealed by a Survey of Noncovalent Interactions in Model Systems. J. Am. Chem. Soc. 2009, 131, 16555-16567.

${ }^{27}$ Stringer, J. R.; Crapster, J. A.; Guzei, I. A.; Blackwell, H. E. Construction of Peptoids with All Trans-Amide Backbones and Peptoid Reverse Turns via the Tactical Incorporation of N-Aryl Side Chains Capable of Hydrogen Bonding. J. Org. Chem. 2010, 75, 6068-6078.

${ }^{28}$ Caumes, C.; Roy, O.; Faure, S.; Taillefumier, C. The Click Triazolium Peptoid Side Chain: A Strong cis-Amide Inducer Enabling Chemical Diversity. J. Am. Chem. Soc. 2012, 134, 9553-9556.

${ }^{29}$ Roy, O.; Caumes, C.; Esvan, Y.; Didierjean, C.; Faure, S.; Taillefumier, C. The tert-Butyl Side Chain: A Powerful Means to Lock Peptoid Amide Bonds in the Cis Conformation. Org. Lett. 2013, 15, 2246-2249.

${ }^{30}$ Angelici, G.; Bhattacharjee, N.; Roy, O.; Faure, S.; Didierjean, C.; Jouffret, L.; Jolibois, F.; Perrin, L.; Taillefumier, $\mathrm{C}$. Weak backbone $\mathrm{CH}^{\cdots} \mathrm{O}=\mathrm{C}$ and side chain $\mathrm{tBu}{ }^{\cdots} \mathrm{tBu}$ London interactions help promote helix folding of achiral NtBu peptoids. Chem. Commun. 2016, 52, 4573-4576.

${ }^{31}$ Gimenez, D.; Aguilar, J. A.; Bromley, E. H.; Cobb, S. L. Stabilising Peptoid Helices Using Non-Chiral Fluoroalkyl Monomers. Angew. Chem. Int. Ed. 2018, 57, 10549-10553.

${ }^{32}$ Kuemin, M.; Engel, J.; Wennemers, H. Temperature-induced transition between polyproline I and II helices: quantitative fitting of hysteresis effects. J. Peptide Sci. 2010, 16, 596-600.

${ }^{33}$ Armand, P.; Kirshenbaum, K.; Falicov, A.; Dunbrack Jr, R. L.; Dill, K. A.; Zuckermann, R. N.; Cohen, F. E. Chiral N-substituted glycines can form stable helical conformations. Fold. Des. 1997, 2, 369-375.

${ }^{34}$ Baskin, M.; Maayan, G. A rationally designed metal-binding helical peptoid for selective recognition processes. Chem. Sci. 2016, 7, 2809-2820.

${ }^{35}$ Tigger-Zaborov, H.; Maayan, G. Aggregation of $\mathrm{Ag}(0)$ nanoparticles to unexpected stable chain-like assemblies mediated by 2,2 '-bipyridine decorated peptoids. J. Colloid Interf. Sci. 2019, 533, 598-603.

${ }^{36} \mathrm{Wu}$, C. W.; Sanborn, T. J.; Huang, K.; Zuckermann, R. N.; Barron, A. E. Peptoid oligomers with $\alpha$-chiral, aromatic side chains: Sequence requirements for the formation of stable peptoid helices. J. Am. Chem. Soc. 2001, $123,6778-6784$.

${ }^{37}$ Wu, C. W.; Sanborn, T. J.; Zuckermann, R. N.; Barron, A. E. Peptoid Oligomers with $\alpha$-Chiral, Aromatic Side Chains: Effects of Chain Length on Secondary Structure. J. Am. Chem. Soc. 2001, 123, 2958-2963.

${ }^{38}$ Shin, H. M.; Kang, C. M.; Yoon, M. H.; Seo, J. Peptoid helicity modulation: precise control of peptoid secondary structures via position-specific placement of chiral monomers. Chem. Commun. 2014, 50 (34), 4465-4468.

${ }^{39}$ Green, M. M.; Reidy, M. P.; Johnson, R. D.; Darling, G.; O'Leary, D. J.; Willson, G. Macromolecular stereochemistry: the out-of-proportion influence of optically active comonomers on the conformational characteristics of polyisocyanates. The sergeants and soldiers experiment. J. Am. Chem. Soc.1989, 111, 6452-6454.

${ }^{40}$ Shyam, R.; Nauton, L.; Angelici, G.; Roy, O.; Taillefumier, C.; Faure, S. NC $\alpha$-gem-dimethylated peptoid side chains: A novel approach for structural control and peptide sequence mimetics. Biopolymers 110, 2019 , e23273.

${ }^{41}$ Hjelmgaard, T.; Faure, S.; Caumes, C.; De Santis, E.; Edwards, A. A.; Taillefumier, C. Convenient SolutionPhase Synthesis and Conformational Studies of Novel Linear and Cyclic $\alpha, \beta$-Alternating Peptoids. Org. Lett. 2009, 11, 4100-4103.

${ }^{42}$ Gorske, B. C.; Blackwell, H. E. Tuning peptoid secondary structure with pentafluoroaromatic functionality: A new design paradigm for the construction of discretely folded peptoid structures J. Am. Chem. Soc. 2006, 128, 14378-14387. 
TOC graphic

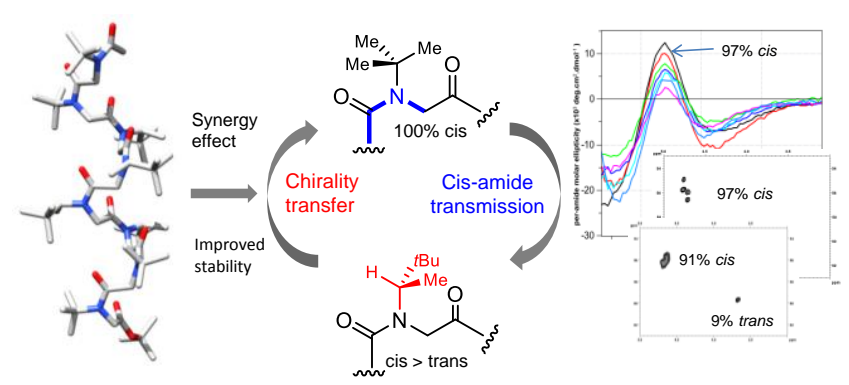

